\title{
MASTER
}

Copy № 27

APAE Memo-310

AEC Research and

Development Report

UC-81, Reactors - Puwer

[Special Distribution]

\section{spent fuel transfer, storage and shipment for PL-3}

Contract No. AT[30-1]-2900

with U. S. Atomic Energy Commission

New York Operations Office

\section{ALCO \\ NPED}

ALCO PRODUCTS, INC. NUCLEAR POWER ENGINEERING DEPARTMENT 


\section{DISCLAIMER}

This report was prepared as an account of work sponsored by an agency of the United States Government. Neither the United States Government nor any agency Thereof, nor any of their employees, makes any warranty, express or implied, or assumes any legal liability or responsibility for the accuracy, completeness, or usefulness of any information, apparatus, product, or process disclosed, or represents that its use would not infringe privately owned rights. Reference herein to any specific commercial product, process, or service by trade name, trademark, manufacturer, or otherwise does not necessarily constitute or imply its endorsement, recommendation, or favoring by the United States Government or any agency thereof. The views and opinions of authors expressed herein do not necessarily state or reflect those of the United States Government or any agency thereof. 


\section{DISCLAIMER}

Portions of this document may be illegible in electronic image products. Images are produced from the best available original document. 
APAE Memo-310

Copy No.

AEC Research and

Development Report

UC-81, Reactors, Power

(Special Distribution)

\section{SPENT FUEL TRANSFER, STORAGE AND SHIPMENT FOR PL-3}
By:
G. C. Hauenstein
D. L. Pomeroy

Approved by:

G. E. Humphries, Project Engineer

Issued: March 7, 1962

Contract No. AT(30-1)-2900

with U. S. Atomic Energy Commission

New York Operations Office

ALCO PRODUCTS, INC.

Nuclear Power Engineering Department

Post Office Box 414 


\section{AEC IEGAL NOTICE}

This report was prepared as an account of Government sponsored work. Neither the United States, nor the Commission, nor any person acting on behalf of the Commission:

A. Makes any warranty or representation; expressed or implied, with respect to the accuracy, completeness, or usefulness of the information contained in this report, or that the use of any information, apparatus, method, or process disclosed in this report may not infringe privately owned rights: or

B. Assumes any liabilities with respect to the use of, or for damages resulting from the use of any information, apparatus, method, or process disclosed in this report.

As used in the above, "person acting on behalf of the Commission" includes any employee or contractor of the Commission, or employee of such contractor, to the extent that such employee or contractor of the Commission, or employee of such contractor prepares, disseminates, or provides access to, any information pursuant to his employment or contract with the Commission, or his employment with such contractor.

\section{ALCO LEGAL NOTICE}

This report was prepared by Alco Products, Incorporated in the course of work under, or: in connection with; Contract No. AT(30-1)-2900, issued by U.S. Atomic Energy Commission, NYOO; and subject only to the rights of the United States, under the provisions of this contract, Alco Products, Incorporated makes no warranty or representation, express or implied, and shall have no liability with respect to this report or any of its contents or with respect to the use thereof or with respect to whether any such use will infringe the rights of others.

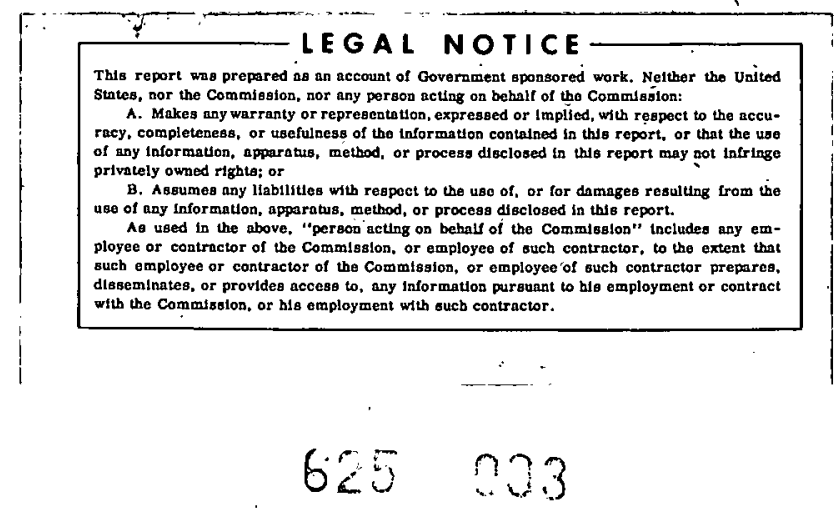


External Copies

$1 \ldots 2$ New York Operations Office

U.S. Atomic Energy Commission

c/o Alco Products, Inc.

1 . Nott Street

Schenectady 5, New York

Attention: Resident Engineer, PL-3

$3-4 \quad$ New York Operations Office

U. S. Atomic Energy Commission

376 Hudson : Street

New York 14, New York

Attention: Project Engineer, PL-3

Reactor Division

5 - 9 U.S. Atomic Energy Commission

Washington .25, D. C.

Attention: Chief, Water Systems Branch

(Army Reactors)

Division of Reactor Development

Mail Station F-311

10

U. S. Atomic Energy Commission

Washington 25, D. C。

Attention: Chief, Water Reactors Branch

Civilian Power

Division of Reactor Development

Mail Station F-311

11

U.S. Atomic Energy Commission

Chief, New York Patent Group Brookhaven National Laboratory Upton, New York

Attention: Harmon Potter

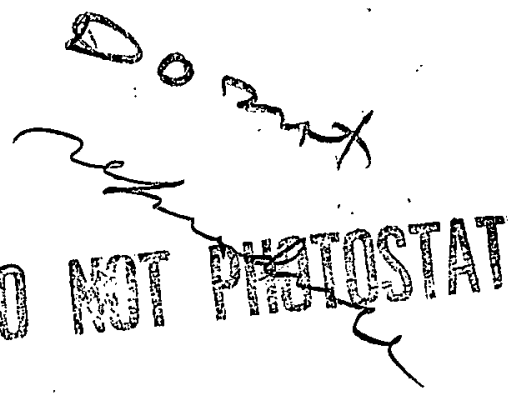


External

Copies

12 U. S. Atomic Energy Commission

Office of the General Counsel

Washington 25, D.C.

Attention: Mr. Roland Anderson

13 U.S. Atomic Energy Commission

Idaho Operations Office

P. O. Box 2108

Idaho Falls, Idaho

Attention: Director, Division of Military Reactors

14 U. S. Atomic Energy Commission

Reports and Statistics Branch

Division of Reactor Development

Washington 25, D.C.

15 - 19 Bureau of Yards and Docks

Navy Department

Washington 25, D. C。

Attention: Director, Nuclear Power Division

Code E-300

20 Office of the Chief of Engineers

Department of the Army

Building $T-7$

Washington 25, D.C.

Attention: Chief, Projects Branch

Nuclear Power Division;

21 Nuclear Power Field Office

U.S. Army Engineer Reactors Group

Fort Belvoir, Virginia

Attention: Chief, Nuclear Power Field Office 


\section{DISTRIBUTION (CONT'D)}

External

Copies

22

23

24

25

26

$27-29$
Sundance Air Force Radar Station P. O. Box 80

Sundance, Wyoming

Attention: AEC Site Representative, - PM-1

Nuclear Power Field Office

U. S. Army Engineer Reactors Group

Fort Belvoir, Virginia

Attention: O. I。C. SM-1

Chief, U.S. Army Reactors Group

Fort Greely, Alaska

APO 733

Seattle, Washington

Attention: O. I. C. SM-1A

Commanding Officer

U. S. Army Polar Research and Development Center

Fort Belvoir, Virginia

Attention: Nuclear Power Officer

Commander

Air Force Special Weapons Center (AFSWC)

Albuqerque, New Mexico

Attention: SWVP

Office of Technical Information Extension

P. O. Box 62

Oak Ridge, Tennessee

Union Carbide Nuclear Corporation

Oak Ridge National Laboratory

Y-12 Building 9704-1

P.O.Box "Y"

Oak Ridge, Tennessee

Attention: Mr。L.D. Schaffer 


\section{DISTRIBUTION (CONT'D)}

External

Copies

31

32

33

34

35

36
Director

U.S. Army Cold Regions

Research and Engineering Laboratpries

P. O. Box 282

Hanover, New Hampshire

Attention: Dr. R.W. Gerdel

Advanced Technology Labo ratories

Division of American-Standard

369 Whisman Road

Mountain View, California

Attention: Director, Research and Development

Aerojet General Nucleonics

Military Products. Division

Box 77

San Ramon, California

Attention: Manager

The Babcock \& Wilcox Company

Atomic Energy Division

1201 Kemper Street

P. O. Box 1260

Lynchburg, Virginia

Attention: Manager

Combustion Engineering, Inc.

Nuclear Division

Prospect Hill Road

Windsor, Connecticut

Attention: Mr。J.B. Anderson

General Atomic

Division of General Dynamics

P. O. Box 608

San Diego 12, California

Attention: Assistant Laboratory Director

vi 


\section{DISTRIBUTION (CONT'D)}

\begin{tabular}{l} 
External \\
Copies \\
\hline
\end{tabular}

37

General Electric Company

Atomic Power Equipment Department

2151. South First Street

San Jose 12, California

Attention: Manager, Fngineering

38 Lockheed-Georgia Company

Lockheed Nuclear Products

Marietta, Georgia

Attention: Director, Nuclear Laboratories

39

The Martin Company

P. O。Box 5042

Middle River, Maryland

Attention: : AEC Contract Document Custodian

$40 \quad$ United Nuclear Corporation

Development Division

5 New Street

White Plains, N. Y。

Attention: Library Custodian

41 Westinghouse Electric Corporation

Atomic Power Department

P.O.Box 355

Pittsburgh 30, Pennsylvania

Attention: Director of Projects 


\section{DISTRIBUTION (CONT $\left.{ }^{i} \mathrm{D}\right)$}

Internal

Copies

K. Kasschau

63

E. S. Haraway

43

$\mathrm{J}$ 。 $\mathrm{G}_{\circ}$. Gallagher

64

H. N. Roberts

44

J. F. Haines

$65-66$.

PL-3 File

G. E. Humphries

$67-71$

NPED File

N. F. Taylor

47

J. H. Mackin

48

R. E. Williams

49

P.E. Bobe

50

W. O. Enright

51

E. L. Cofrances

52

R. M. Ryan

53

J. F. Scoles

54

D. Pomeroy

55

G. Hauenstein

56

G. M. Van de Mark

57

H. V. Gestwicki

58

R.W. Kelleman

59

J. H。 Noble

60

J.P. Tully

61

D. Polinak

62

D. H. Hyatt 


\begin{abstract}
In refueling development studies performed on PL-3 Phase I design, several methods of fuel transfer, storage, and shipment were investigated. An evaluation of the relative merits of the systems and designs under study, as applied to either the BWR or PWR concepts, is made and optimum designs are selected. An analysis of spent fuel shipping cask shielding requirements is presented, along with recommendations for future study in this area.
\end{abstract}


ABSTRACT -

1. 0 SUMMARY $\ldots \ldots \ldots$

2.0 INTRODUCTION $\ldots \ldots \ldots$

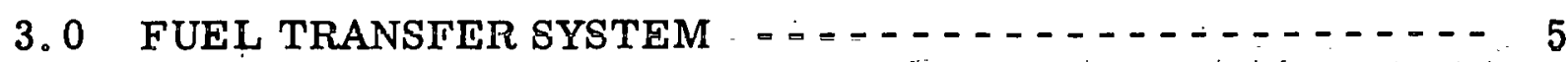

3.1 Fuel Transfer by Flask $-\ldots \ldots$

3.2 Fuel Transfer by Spent Fuel Chute - $\ldots \ldots$

3.3 Fuel Transfer by Carriage - $\ldots$

4. 0 STORAGE OF SPENT FUEL ELEMENTS $\ldots \ldots \ldots$

4.1 Storage in Shielded Spent Fuel Tank _ _ _ _ _ _ _ _ 11

4. 2 Storage in Shipping Cask in Peripheral Tank

4. 3 Storage in Shipping Cask in Tank on Skid - - 12

5. 0 SHIPPING OF SPENT FUEL ELEMENTS

5.1 Cask Size -

5.2 Cask Design $-\ldots \ldots \ldots \ldots$

5.3 Cask Shipment $\ldots \ldots \ldots \ldots$

6. 0 TOOLING REQUIREMENTS FOR REFUELING $\ldots \ldots \ldots$

7. 0 SPENT FUEL SHIPPING CASK SHIELDING STUDY $-\ldots$

7.1 Requirements -

7.2 Description of Cores -

7.2.1 PWR, $7 \times 7$, Type 2 -

7.2.2 PWR, $5 \times 5$, Type 3 - - - -

7.2.3 BWR High Enrichment Plate Type Core - - - - - 18

7.2.4 BWR Low Enrichment Rod Type Core - - - - - - 18 
TABLE OF CONTENTS $\left(\right.$ CONT $\left.^{\circledR} \mathrm{D}\right)$

Page

7.3 Calculation Methods - 3 - 18

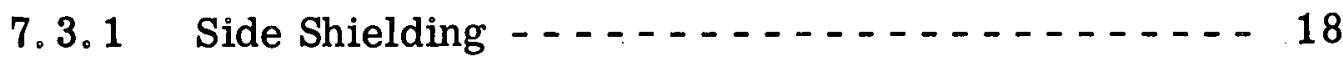

7.3.2 End Shielding _..........

7.4 Results $\ldots \ldots \ldots \ldots \ldots$

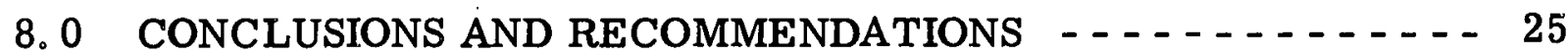

9.0 BIBLIOGRAPHY $\ldots \ldots \ldots \ldots \ldots \ldots$

APPENDIX A - TABLES - - $\ldots \ldots \ldots$

APPENDIX B - FIGURES - - $\ldots \ldots \ldots-\ldots, \ldots-\ldots$ 


\section{LIST OF TABLES}

\section{(APPENDIX A)}

$\underline{\text { Table }}$

1

2

3

4

5

6
Title

Page

Shipping Cask and Transfer Flask Data Sheet

31

Decay Heat Generation Rates, PL-3 Core

32

Fuel Transfer Tooling for the PL-3 keactor

33

Refueling Time Estimate for Boiling Water

Reactor Fuel Transfer by Transfer Flask

34

Refueling Time Estimate for Pressurized Water

Reactor Fuel Tranșfer by Spent Fuel Chutes to

Shipping Casks

35

Core: Data $^{*}: \cdots, \ldots \ldots$

Source and Shielding Data 


\section{LIST OF ILLUSTRATIONS}

\section{(APPENDIX B)}

$\underline{\text { Figure }}$
'I'itle

Page

Fuel Transfer Flask (Dwg. AEL-731)

39

Refueling Concept Using Transfer Flask

41

Boiling Watcr Reactor Complex (Dwg. AEL-710)

43

Primary System, PWR Complex C-5 (Dwg. AEL-762)

45

Spent Fuel Chute Concept

47

Primary System Complex A-3, PWR

49

Storage Cask Forced Cooling System

51

Cask Cooling System

53

Cask Sizing Based on PL-2 Core (BWR Rod Type)

55

Optimum Shipping Cask Arrangement

57

Spent Fuel Shipping Cask (Dwg. AEL-735)

59

Proposed Skid - Spent Fuel Shipping Cask

61

Shielding Requirements for Shipping a $\mathrm{PWR}, 7 \times 7$ Type 2 Core

Shielding Requirements for Shipping a PWR, $5 \times 5$ Type 3 Core

Shielding Requirements for Shipping a BWR Plate Type Core

Shielding Requirements for Shipping a BWR Rod Type Core

Shipping Cask Shield Reduction for Partial Cores

71

Shipping Cask. Dose Attenuation 


\section{0 SUMMARY}

The study and evaluation of several different refueling, storage: and shipping methods has yielded the following results:

1. The optimum transfer system for the BWR concept is one in which fuel is removed, carried in, and deposited by a flask. Location of selected elements for transfer is achieved by an index plate in the shield cover assembly placed over the reactor vessel flange. Element grappling tools are incorporated in the flask design.

2. The optimum transfer system for the PWR concept is one which utilizes a fuel chute or chutes through the vapor container wall. Fuel is manually transferred by hand tools from the reactor to the storage receptacle. Adequate personnel protection is provided by the shield water, and vapor containment is maintained by a seal plug in the chute.

3. The :optimum storage arrangement is one which utilizes the shipping cask as a spent fuel receptacle, thereby saving the weight of shielding that would be necessary for a spent fuel tank storage facility. Further refinement will be required to arrive at the best natural convection cooling system for these casks.

4. The optimum shipping cask arrangement for the reference core is four units if the $20,000 \mathrm{lb}$ shipping weight limit is not to be exceeded, and two casks if the gross shipping weight is 27,500 lb.

5. To provide an optimum weight spent fuel shipping cask, a series of analytical shielding calculations were performed. The graphical results may be used to determine the shield requirements, optimum cask size and decay time before shipment. 


\section{0 INTRODUCTION}

Studies were undertaken under Phase I of the PL-3 contract, which consisted of the following areas in development of a reactor refueling system for PL-3:

1. Development of a fuel transfer system

2. Storage of spent fuel, elements

3. Shipping of spent fuel ellements

4. Tooling r.equirements for refueling

Each of the above topics was necessarily considered individually. The study of a fuel transfer, storage, and shipment was based on two different reactor types and four different fuel cores. The positioning of the control rod drives above or below the reactor core affected the fuel transfer time.

A basic design requirement kept the maximumum shipping weight of any unit below a maximum of $20,000 \mathrm{lb}$ and within a package size of $8 \times 8 \times 30 \mathrm{ft}$. A literature survey and study of existing techniques preceded the development study on any of the systems. 


\section{0 FUEL TRANSFER SYSTEM}

The development of the spent fuel transfer system was to some extent predicated on the reactor type. For boiling water reactors (BWR) it is undesirable to penetrate the reactor vessel wall with fuel chutes or tubes to transfer spent elements. Therefore, transfer by flask to an adjacent or slightly removed storage area is the appropriate system. Any of the fuel transfer concepts investigated could be applied to a pressurized water reactor (PWR), so selection of a system for use with this type reactor was based on cost, ease of maintenance, and reliability. The following three methods were investigated.

\subsection{FUEL TRANSFER BY FLASK}

A typical flask design for transfer of spent fuel elements is shown in Dwg. AEL-731 (Fig. 1)*. This design is based on the BWR plate type element and cruciform rod as proposed on one of the BWR concepts. At the bottom of the flask there is an adapter ring that locates the flask on the index plate. Just above the adapter is a sliding shield gate that is operated by handwheel from the top of the flask. The screw actuated slide gate is more desirable than the rotating plug type gate, for PL-3 application, for it can be made smaller and will weigh less.

The fuel element or absorber will be housed in the cylindrical cavity above the shield gate during transfer. The grappling tools, for engagement of fuel elements or absorbers, are raised or lowered by the handwheel on the top of the flask connected to the horizontal shaft. Accidental dropping of the unit being handled is prevented by a ratchet wheel and pawl on the horizontal shaft. During lifting, the spring loaded pawl will cam out of engagement, but will hold if the handle is released. During lowering operations, the pawl release on the handle is depressed, holding the pawl out of engagement with the ratchet. Removal of the hand intentionally or accidentally will immediately engage the pawl with the ratchet wheel and prevent dropping of the element. The space limitations may necessitate use of a grappling tool built in two or three sections, and the sections would be removed or added during the transfer operation. The tool configurations will be contingent on the final design of the fuel element and absorber.

Transfer by spent fuel flask would probably utilize a system similar to that depicted in Fig. 2. Following is a complete procedure for this transfer as it would apply to a BWR, concept such as that shown in Dwg. AEL-740 (Fig. 3). Drawing AEL-740 is used for reference on steps 1-10, and Fig. 2 is used for steps 11-29.

* All figures are in Appendix B. 
1. Pump water into reactor vessel until completely full.

2. Drain water from upper shield tanks and remove.

3. Remove shielding from around control rod drive units.

4. Remove control rod drive units and place in stoned position.

5. Unbolt and remove vapor container dome.

6. Remove control rod drive thimbles and delatch control rods.

7. Remove control rod extensions and racks.

8. Crack open nuts on reactor vessel.

9. Drain reactor vessel to flange level and remove cover nuts.

10. Remove and store vessel cover with housing and steam dryer attached.

11. Place shield cover over reactor vessel flange in proper position.

12. Rotate section guide to desired location.

13. Rotate element guide to position over desired element.

14. Position transfer flask on element guide, with proper tool in flask.

15. Open viewing port and check that shield gate is open on flask.

16. Crank grappling tool down until contact is made with element.

17. Engage element with tool。

18. Close viewing port and raise element into flask, monitor radiation.

19. Close shield gate at bottom of flask, monitor radiation.

20. Lift flask by crane and position over shipping cask in shield tank; monitor radiation.

21. Check locating adapter on shipping cask to assure proper position.

22. Lower transfer flask until it engages locating adapter.

23. With extension tool, open bottom shield gate in flask.

24. With extension tool, lower element from flask into shipping cask. 
25. Disengage element from grappling tool and withdraw tool.

26. Raise transfer flask slowly, monitoring radiation.

27. Check transferred element for proper positioning.

28. Move locating adapter on cask to next selected position.

29. Repeat process, steps 12-28 until all of fuel is transferred.

It will be necessary to supply sufficiently thick lead shielding around the top of the reactor (shield cover) to reduce radiation to a safe level for operating personnel. This shielding would be based on the hottest element in the core. The transfer flask will probably require an air or liquid cooling system, to assure adequate cooling in event of equipment failure causing the loaded flask to be held out of the water. Heat release from a hot element after one day cooldown could run as high as $13,380 \mathrm{Btu} / \mathrm{hr}$. For calculating purposes, the hottest element is figured to be $150 \%$ of average.

The transfer flask could also be used with a spent fuel pit, where elements would be stored in racks instead of casks. In this application, it would be advantageous to use a second indexing shield cover over the pit to preclude any chance of the transfer flask dropping onto a loaded spent fuel stórage rack.

In using a transfer flask with a pressurized water reactor, the cover shield could be used and placed on the top of the vapor container flange. A simpler and less expensive approach would be to use an indexing adapter plate on the reactor vessel flange and to lower the flask to this level for operation, utilizing the reactor shield water for radiation protection.

\subsection{FUEL TRANSFER BY SPENT FUEL CHUTE}

A typical reactor configuration using a spent fuel chute is depicted in Dwg。AEL-762 (Fig. 4), and a chute assembly is shown in Fig。 5. To maintain vapor container integrity, a seal plug, capable of withstanding maximum anticipated pressure in event of accident must be inserted in the chute. This plug is seated against a tapered shoulder in the fuel chute and then the rubber seal is tightened against the tube wall, forming a leak-tight closure. At the lower or discharge end of the chute is a hopper fabricated of the same size pipe as that used in the chute. This hopper can be latched in alignment with the chute or in the vertical position. Operation of the hopper is performed with the same tool that is used for control rod element and absorber removal. Using Dwg. AEL-762 (Fig. 4) and Fig. 5 for reference, the following procedure is used in refueling after shutdown of the reactor:

1. Remove vajpor container cover bolts.

2. Remove and store vapor container cover. $625 \quad 013$ 
3. Remove cable net (if used) and store.

4. Fill, unbolt, and remove dry cap (if used).

5. Remove and store reactor vessel cover nuts.

6. Lift cover from reactor vessel and store.

7. Remove and store core cover.

8. Remove and store control rod caps

9. Loosen, remove, and store plug from fuel chute.

10. Check fuel chute hopper for alignment with chute.

11. Using appropriate tool, engage fuel element or absorber.

12. Lift element from core, place in chute and lower into hopper.

13. Disengage and remove tool.

14. Unlatch hopper and rotate to vertical (unloading) position.

15. Engage element, lift from hopper and place in storage receptacle.

16. Unlatch and rotate hopper to align with fuel chute.

17. Repeat steps 10 through 16 until core is transferred.

In the event that the spent elements are to be stored in shipping casks for cooling, there may be a fuel chute for each shipping cask required. To protect personnel from radiation during transfer to a shipping cask, a U-shaped auxiliary shiled would be placed on the top of the cask being loaded. This shield would be moved from cask to cask as transfer progresses. The chute plugs would be removed from all the chutes at the start of refueling operations and replaced at the completion of transfer. The number of chutes required would be contingent on the number of casks needed to ship an entire core. Transfer to shipping casks would utilize the cask shielding and eliminate the heavy shielding required on a spent fuel storage tank.

\section{3 FUEL TRANSFER BY CARRIAGE}

This system of fuel transfer involves placing the spent fuel element on a ghided carriage and mechanically traversing the carriage through 2-pipe tunnel to a fuel storage area. The complexity of the mechanism, higher cost, and 
difficulty of maintenance: exclude this system for any reactor arrangement except one in which the fuel pit is somewhat removed from the reactor shielding. Even if the storage tank is in a removed position, transfer by flask would undoubtedly prove to be as fast, more reliable, and easier to maintain...? 


\section{0 STORAGE OF SPENT FUEL ELEMENTS}

There are numerous methods of storing fuel elements during decay after removal from a reactor. The following approaches to storage of spent PL-3 cores were investigated:

1. Storage in shielded spent :fuel tank

2. Storage in shipping "čask in peripheral tank

3. Storage in shipping cask in tank on skid

Each of these systems has advantages and disadvantages as will be shown in the following description.

\section{1 STORAGE IN SHIELDED SPENT FUEL TANK}

This storage method can be utilized whether the fuel is transferred by flask or chute. The spent fuel tank would be cylindrical in shape and heavily shielded. On the side of the tank adjacent to the vapor container, shielding may be largely eliminated, as shown in Dwg. AEL-732 (Fig. 6). Inside the tank there are two storage racks, each capable of holding an entire spent core. These racks would allow free flow of coolant water through and around the elements by natural convection. The rack material would be $1 \%$ boron type steel to reduce neutron activity to a minimum. The base of the rack would be elevated sufficiently from the tank floor so that convectional cooling will not be impaired. Around the tank there would be adequate lead shielding to keep radiation to acceptable site. levels. The water level in the tank will provide required shielding for the operating crew.

\section{2 STORAGE IN SHIPPING CASK IN PERIPHERAL TANK}

In this system, the fuel is loaded directly into the shipping cask from a transfer flask (see Fig。2) or placed in the cask after removal from the spent fuel chute. The shipping cask in this application provides the shielding required. After loading of the cask, the cover would be supported on a pedestal mount above the shipping cask. This arrangement would eliminate direct gamma streaming and would reduce scattering of gamma rays. When first loaded, the spent fuel elements have a high heat dissipation. Investigation of cooling by natural convection is being undertaken and indications are that proper sizing of flow areas at the top and bottom of the cask should permit cooling by this method. In the event that cooling by natural convection proves impractical, an arrangement for forced çirculation has been devised, utilizing the siphon drain at the bottom of the cask (Fig. 7). 


\subsection{STORAGE IN SHIPPING CASK IN TANK ON SKID}

This storage method would be used if it is desirable to use the cask shielding in place of a shielded tank, and sufficient storage space is not available in the shield or transfer tank. The elements would be loaded directly from the reactor into the shipping cask, utilizing either a spent fuel chute or transfer flask. As soon as the cask loading is completed, the cover is lowered onto the cask and the assembly is lifted from the tank and placed in a small tank on the skid. From the time that the cask is closed, until it is placed in the skid tank, cooling is dependent on natural convection. As soon as the cask is in the skid tank, a forced convection cooling system is hooked up and started (Fig. 8). The cover nuts are then applied and tightened and the cask secured with skid hold downs. During transportation of the skid to a storage room, the circulating pump is powered by battery. When the skid is placed in the storage room, the pump is placed on rectified plant power. After the heat generation has decreased due to time in storage, the pump may be bypassed and the cask cooled by closed loop natural convection. This system has the inherent hazard of element overheat if the removal of the closed cask from the transfer or shield tank is delayed by mechanical failure. The delay of securing the cover to the cask while it is still in the transfer tank could cause element overheat provided the closed cask cannot be cooled sufficiently by natural convection and conduction. The hazard potential of this system makes it undesirable for use with the PL-3 plant. 


\section{0 . SHIPPING OF SPENT FUEL ELEMENTS}

The design of a shipping cask for spent fuel elements is contingent on the following factors :

1. Number of elements to be shipped in cask.

2. Required shielding for selected number of elements.

3. Weight and physical size of elements.

4. Maximum weight permissible for assembled,loaded cask.

\section{1 CASK SIZE}

In arriving at an optimum cask size, all the above items must be integrated into a cask arrangement that is feasible. The sizing of the casks is pictorially demonstrated in Fig. 9, based on BWR rod type elements which weigh approximately $200 \mathrm{lb}$ each. The six element casks, requiring four casks per core, is above the allowable gross weight of $20,000 \mathrm{lb}$ for the bare cask alone. To attempt to ship the same core in five casks, the irregular configuration shown would be required and the weight of the bare cask would be only slightly reduced, remaining too high. To ship the core in six casks, the 4 element casks would be within the weight limit. Three of the six casks would require a channel in the cask wall to allow a second cruciform rod in the cask ( 9 cruciforms per core). This channel would be surrounded by a depleted uranium insert to reduce radiation to an even intensity around the cask. It is possible, since absorber life exceeds that of the fuel elements, that the channel could be eliminated and partial shipments of cruciforms made with each spent core shipment. This same principle might be applied to square absorbers used in control rod assemblies, thereby reducing the number of compartments required per shipping casks. This might also reduce the size and weight of each cask.

The optimum shipping cask arrangement for three different cores is shown in Fig. 10. The shielding on which the designs were based ' was derived from the ROC code developed by Alco Products, Inc. Data regarding these casks and the casks for the PWR $5 \times 5$, Type 3 element core are presented in Table 1 (Appendix A). The shielding development is covered in Section 7.0 of this report.

\subsection{CASK DESIGN}

All cask design is predicated on the requirements of the I. C. C. , A. E. C. and I. C. P. P. regulations, as well as the logistic limitations for the PL-3 site. It is anticipated that loaded spent fuel shipping casks will be fløwn from Byrd. 
Station to McMurdo Sound, carried by boat from McMurdo Sound to the United States and then transported by truck and rail from the port of entry to the processing plant. Shielding design will be based on maximum dose rates for any carrier used.

A typical shipping cask design is shown in Dwg. AEL-735 (Fig. 11). This design is for fifteen PWR, $7 \times 7$, Type 2 fuel elements in a $3 \times 5$ arrangement. This cask would hold $1 / 4$ core for the PWR, $7 \times 7$, Type 2 arrangement or $1 / 2$ core for the PWR, $5 \times 5$, Type 3 arrangement, since overall dimensions of the elements are almost identical. Shielding would be slightly thicker for the half core cask than for the quarter core cask.

\section{3 CASK SHIPMENT}

When the cask is shipped, it will be dry and heat dissipation will be through the walls of the cask. The heat removal requirements for fractional parts of a core after various periods of decay following shutdown are presented in Table 2 (Appendix A). It is readily seen that shipment of fuel 90 days to a year after shutdown of the reactor will involve much less heat removal than during the period right after shutdown. This decline in decay heat generation allows shipment without auxiliary cooling systems. A conceptual design of a skid for shipment of casks is shown in Fig. 12. The skid will be sized to accept the base mounting dimensions of the cask and to allow angular orientation without tripping over. Four adjustable tie downs will secure the upper portion of the shipping cask to the skid. 


\section{0 TOOLING REQUIREMENTS FOR REFUELING}

The tooling required to perform refueling of the PL-3 reactor will be contingent on final design of the reactor vessel, vapor container, core cover, transfer method, storage method, fuel element and absorber size, and end configurations. A listing of the anticipated tooling is presented in Table 3 (Appendix:A). Limited clearance above the operating floor level may necessitate design of some tools with either telescoping or sectional handles. Telescoping tools of Alco design have been successfully used for several years at the SM-1 reactor site.

If a specific tool is required at more than one location, it will be made in duplicate to accelerate operations. All tools subject to wetting will be designed of corrosion resistant material. The time required to make a complete fuel transfer will vary considerably with the method of refueling. Estimated times for refueling operations on the.BWR and PWR concepts are shown in Tables 4 and 5 respectively. These figures are based on a four man refueling crew, using tools as listed in Table 3. 


\subsection{SPENT FUEL SHIPPING CASK SHIELDING STUDY}

\subsection{REQUIREMENTS}

As previously discussed in this report, spent fuel elements will be shipped to a reprocessing station in the U. S. in lead shielded casks by air, sea, and land routes. The logistics of Byrd Station dictate severe weight limitations on the shipping casks. To optimize for a minimum total weight of fuel casks the shielding requirements and the effects of decay time and number of elements per cask must be determined.

In addition to the requirement that the total weight be minimum, Appendix B - Technical Provisions to Contract AT(30-1)-2900 PL-3, and revisions, provides the following guidelines for shipping casks:

1. Casks shall conform to Idaho Chemical Processing Plant shipping cask requir ements.

2. The number of casks shall be adequate to load two complete cores at one time.

3. Casks and fuel shall be protected to prevent damage by an ambient temperature of $-100^{\circ} \mathrm{F}$.

4. Maximum weight of $20,000 \mathrm{lb}$ going in, and $27,000 \mathrm{lb}$ flying out, for a single cask.

The casks are also designed in accordance with the AEC proposed rule 10 CFR Part 72,"Protection Against Radiation in the Shipment of Irradiated Fuel Elements."

The task consisted of performing calculations on an IBM-650 computer to determine the side shielding requirements for four PL-3 core concepts. Modifications to the machine results were made to evaluate the requirements for partial cores. The shield requirements for the ends of the selected core cask were determined on the basis of a hand calculation model.

\subsection{DESCRIPTION OF CORES}

\subsubsection{PWR $7 \times 7$, Type 2}

This core is composed of fuel elements and absorbers similar to those currently employed in the SM-1, Core II at Ft. Belvoir, Va. The core employs flat plate fuel elements composed of a highly enriched $\mathrm{UO}_{2}$ stainless steel matrix 
clad with low cobalt stainless steel. The fuel plates are 30 mils thick, including the $5 \mathrm{mil}$ cladding on each side of the fuel matrix. Control is accomplished by seven box-type absorbers with fuel element followers. The absorbers are composed of $\mathrm{Eu}_{2} \mathrm{O}_{3}$ in stainless steel, clad with stainless steel.

\subsubsection{PWR 5 x 5,Type 3}

This core is composed of fuel elements and absorbers similar to those employed in the $7 \times 7$, Type 2 core. The Type 3 fuel plates are 40 mils thick, including 5 mils of cladding on each side of the fuel matrix. The fuel matrix of the Type 3 element is slightly wider than that of the Type 2 element and employs a slightly reduced weight percent of $\mathrm{UO}_{2}$.

\subsubsection{BWR High Enrichment Plate Type Core}

The dimensions of these fuel assemblies and plates are nearly the same as the $5 \times 5$, Type 3 core described above, except that the fueled portion of the fuel is 28 in. long instead of 21.75 in. long. Because of the need for larger flow channels in a BWR, the number of fuel plates per assembly was reduced from 18 to 8 .

Additional information on the above cores may be found in AP Note-408, (1) the PL-3 Concept Selection Report.

\section{2.4. BWR Low Enrichment Rod Type Core}

Each of the 24 fuel assemblies in this core consist of 59, 20-mil wall, stainless steel tubes containing low enriched $\mathrm{UO}_{2}$ pellets. The rods are 0.42 in. in diameter. The fuel height is 38.3 in. Additional information on this core may be obtained from 100-19030-CEND-135, 2 ) the PL-2 Final Design Report.

Table 6 (Appendix) gives core data used in the shielding calculations.

\subsection{CALCULATIONAL METHODS}

\subsubsection{Side Shielding}

The shielding requirements for the sides of the shipping cask 10 days after reactor shutdown were calculated by using an IBM-650 computer and the ROC shielding codes. A detailed discussion of the ROC shielding program may be found in APAE Memo-142. (3)

The ROC code was first used to determine the source strength of the irradiated fuel. The average fast and thermal neutron fluxes, the volume fraction of the various core materials, and the material properties for the neutron irradiation, are input to this code. Material properties may be found in APAE Memo-145: (4) The output consists of the volume source strength in photons 
per cc per second and the core cross-section in $\mathrm{cm}^{-1}$. An infinite operating time is assumed. Table 7 (Appendix) shows the source output for the four cores.

The shielding calculations done by the ROC code are patterned after a cylindrical source model as discussed in the Reactor Shielding Design Manual(5) using build-up factors and self-attenuation distances from curve fits in APAE Memo-52。(6)

Since the shipping cask will not be shipped within 10 days after reactor shutdown and since the core will not have an infinite operating history, adjustments were made to the ROC output.

In order to determine the dose rates due to the activation of stainless steel, input to the ROC code was adjusted so that a source strength with and without stainless. steel activation was obtained. The ROC shielding calculation was done with both source strengths. The two resulting doses from the above ROC calculations were then adjusted for 2 yr of reactor operation and for various decay times from $2 \mathrm{hr}$ to $10 \mathrm{yr}$. Decay information for fission products was obtained from reference (7) taken for the controlling energy group from the ROC codes (1-3 Mev). Stainless steel decay and activation infonmation came from reference (8).

Since it seemed quite likely that an entire core could not be shipped in one cask due to weight limitations, the lead thickness required for partial cores was investigated.

The equation the code uses for the full core side dose rate is as follows: $(3),(5)$

$$
\begin{aligned}
\mathbf{D}= & \frac{\mathrm{S}_{\mathrm{V}} \mathrm{Ro}^{2}}{2(\mathrm{a}+\mathrm{z}) \mathrm{Ce}} \mathrm{F}\left(\mathrm{b}_{1}, \theta\right) \\
\mathrm{D} & =\text { dose rate }(\mathrm{r} / \mathrm{hr}) \\
\mathrm{S}_{\mathrm{V}} & \left.=\text { volumetric source strength (photons } / \mathrm{cm}^{2} \mathrm{sec}\right) \\
\mathrm{Ro} & =\text { core radius }(\mathrm{cm}) \\
\mu_{\mathrm{S}} & =\text { macroscopic cross-section of core }\left(\mathrm{cm}^{-1}\right) \\
\mathrm{z} & =\text { self-absorption distance }(\mathrm{cm}) \\
\mathrm{b} & =\mu \mathrm{t} \text { (macroscopic cross-section of shield } \mathrm{x} \text { shield thickness) } \\
\theta & =\text { half the angle between the dose point and the top and bottom } \\
\mathrm{Ce} & =\text { of the core }
\end{aligned}
$$

$$
625023
$$




$$
\begin{aligned}
& F(b, \theta)=\int_{0}^{\theta} e^{\left(-b \sec \theta^{\prime}\right)} d \theta^{\prime} \quad(\text { curves are given in Rockwell) })^{(5)} . \\
& b_{1}=b+\mu_{s^{z}}
\end{aligned}
$$

The partial core dose rates were calculated as follows:

$$
D_{\text {partial core }}=D_{\text {full core }} \times \frac{(R o)_{p}^{2} F\left(\theta, b_{1}\right) p\left(a+z_{f}\right)}{(R o)_{f}^{2} F\left(\theta, b_{1}\right) f\left(a+z_{p}\right)}
$$

\subsubsection{End Shielding}

The cylindrical geometry model used by the ROC code cannot be used to determine the end shield requirements.

Since the source diameter is small relative to the distance to the dose point, a model using a series of 6 point sources was used to determine the dose from the ends of the shipping cask. The sources were located on the vertical center line of the fuel. Their location and weight fraction were determined by a Gaussian method of quadratures.(9)

The equation for the dose rate from one point source of one energy with one lead thickness is:

$D=\frac{V C e S_{v}}{4 \pi R^{2}} \quad$ B A F exp $\left(-\mu_{s} t_{s}-\mu_{L} t_{L}\right)$

$\mathrm{V}=$ volume of core $\left(\mathrm{cm}^{3}\right)$

$\mathrm{Ce}=$ flux to dose conversion factor

$\mathrm{S}_{\mathrm{v}}=$ volume source strength $\left(\mathrm{mev} / \mathrm{cm}^{3}-\mathrm{sec}\right)$

$B=$ dose build-up factor $B=f\left(\mu_{s} t_{s}+\mu_{\mathrm{E}} t_{\mathrm{t}}\right)$

$A=$ Gaussian weighting factor

$F \cdot=$ flux factor

$\mu_{\mathrm{s}}=$ macroscopic cross section of core $\left(\mathrm{cm}^{-1}\right)$

$\mu_{\mathrm{L}}=$ macroscopic cross section of shield $\left(\mathrm{cm}^{-1}\right)$

$\mathrm{t}_{\mathrm{S}}{ }=$ thickness of core $(\mathrm{cm})$

$\mathrm{t}_{\mathrm{L}}=$ thickness of lead $(\mathrm{cm}) \quad 62024$

$\mathrm{R}=$ distance from dose point to point source $(\mathrm{cm})$ 
Since 24 solutions ( 4 energies $\times 6$ point sources) to the $D$ equation were required to obtain the total dose for each leak thickness, a Fortran IBM-650 computer program was written for its solution.

Volume source strengths for fission products at $2500 \mathrm{hr}$ after shutdown were obtained from reference.(7). These source strengths were calculated in four energy groups. The stainless steel activation source strengths were obtained from the ROC Code cases previously described.

The total sources used were as follows:

\begin{tabular}{|c|c|c|}
\hline Group & $\begin{array}{l}\text { Energy } \\
\text { Mev }\end{array}$ & $\begin{array}{l}\mathrm{Se} \\
\mathrm{Mev} / \mathrm{cm}^{3} \mathrm{sec}\end{array}$ \\
\hline 1 & 0.7 & $1.37 \times 10^{11}$ \\
\hline 2 & 1.25 & $3.90 \times 10^{9}$ (including S.S. ) \\
\hline 3 & 1.60 & $1.02 \times 10^{9}$ \\
\hline 4 & 2.20 & $7.5 * \times 10^{8}$ \\
\hline
\end{tabular}

The build-up factors for lead were obtained from the Reactor Shield Design Manual. (5) However, the $\mu_{t}$ used was taken equal to the $\mu_{t}$ for the lead shielding plus the $\mu_{t}$ for the core.

The flux factors are used to take into account the variation in source distribution over the length of a fuel element. The test report "Gamma Scanning Spent SM-1 Fuel Elements" (10) plots this variation. An average fuel element source distribution curve was derived from these plots. Deviations from the average flux of this source curve were used to derive the flux factors.

Cross sections for the core materials were taken from ANL-5800(11). Lead cross sections were obtained from Rockwell. (5)

\subsection{RESULTS}

Results have been plotted in Figs.13 - 16 for each core showing the lead equivalent shield required to reduce the dose at 1 meter for the full core to $10 \mathrm{mr} / \mathrm{hr}$ for various shutdown times. These curves may be used to determine an optimum shipping time. For example, by delaying shipment from 10 days to 30 days almost $1 \mathrm{in}$. of lead may be saved; by waiting from 30 days to 90 days about 2 in. of lead may be saved; waiting from 90 days to one year, however, will save less than $1 / 2$ inch.

Figure 17 shows the lead thickness reduction for partial core shipment. An examination of the curves shows that even a large reduction in the number of fuel elements shipped in a cask results in only a small lead thickness reduction. This is partially due to the self shielding value of the fuel. Fuel elements

$$
625 \quad 025
$$


in the inner rows of the cask are shielded by the elements in the outer row.

Figure 18 is the dose attenuation curve of the side shield at 10 days for each full core. Also shown in Fig。 18 is the attenuation curve after $2500 \mathrm{hr}$ shutdown for the ends of 15 of the reference core elements operated for $2 \mathrm{yr}$.

The dose rate from the end breaks down as follows:

\begin{tabular}{|c|c|c|}
\hline Energy Group & \multicolumn{2}{|c|}{ Source Energy } \\
\hline 1 & $0.7 \mathrm{Mev}$ & $0.4 \%$ \\
\hline 2 & $1.25 \mathrm{Mev}$ & $10 \%$ (including S. S. \\
\hline 3 & $1.4 \cdot \mathrm{Mev}$ & $20 \%$ \\
\hline 4 & $2.2 \mathrm{Mev}$ & $70 \%$ \\
\hline
\end{tabular}

The dose rate from the sides of the cask, as calculated by the ROC Code, is' from two source energy groups - 0 to $1 \mathrm{Mev}$ is calculated at $0.75 \mathrm{Mev}$ and 1 to $3 \mathrm{Mev}$ is calculated as $2 \mathrm{Mev}$. The low energy group yields answers that are several orders of magnitude lower than the higher (2 Mev) group. The total dose, thus, essentially all comes from sources in the $2 \mathrm{Mev}$ group. By adjusting the input to ROC Code it is possible to separate this dose into two groups, one from the fission products and one from stainless steel. is :

For an SM-1 core operated $2 \mathrm{yr}$ and shutdown $2500 \mathrm{hr}$ the dose breakdown

Fission product dose

S. S. dose $(\mathrm{Co}-60)$
$55 \%$

$45 \%$

It is believed that the stainless steel (Co-60) dose from the ROC Codes is a high contributor because stainless steel is considered to be a $2 \mathrm{Mev}$ source (by the ROC code) when in reality it is nearer a 1.25 average Mev source.

It may be observed from Fig. 18 that the shielding required for the top and bottom of the shipping cask is almost 2 in. less than that required for the sides at the same decay time. Previous reports (12),(13) discussing shielding requirements for the top and bottom of the shield casks indicate thicknesses greater than or equal to the sides.

The discrepancy is due to the use of two different models for calculating shielding requirements for the end and sides. The ROC code calculation for the side shielding is extremely conservative for the following reasons:

1. The code effectively uses a single energy group for calculation.

2. The average energy is assumed to be $2 \mathrm{Mev}$, well above the true effective average energy. 
3. The analytical model used with ROC code is based upon conservative assumptions.

The minimum weight shield which would meet the shipping requirements could be evaluated by judicious experimentation. However, the analysis thus far performed has been sufficient to evaluate the optimum shipping cask size and decay time before shipment. An estimated $15 \%$ to $20 \%$ shield weight savings might result from the experimentation; however, present budget allows only refinement of the shielding calculations on analytical bases. 


\section{0 CONCLUSIONS AND RECOMMENDATIONS}

The work conducted during Phase I activity has evolved the following conclusions and recommendations:

1. The optimum fuel transfer arrangement for a boiling water reactor concept utilizes a fuel transfer flask. The fuel transfer cask is positioned on a lead filled shield cover which encompasses indexing mechanisms to precisely place the flask opening over any selected core element. Grappling tools, manually operated, penetrate the flask top center and will engage and lift the element into the flask. The flask is then moved to the storage receptacle, where it is precisely placed over a selected compartment and the element is lowered into place and released. The shield gate is closed at all times when the irradiated element is inside the flask. A conceptual flask design is shown in Dwg. AEL-731 (Fig. 1, Appendix B).

2. The optimum fuel tranisfer arrangement for a pressurized water reactor concept utilizes a spent fuel chute. The fuel is lifted by a manually held tool, placed in the chute and lowered into the hopper at the discharge end of the chute. The hopper is then rotated to a vertical position and the element is lifted with the same tool (or a duplicate) and placed in a storage compartment. The chute contains a removable seal which will withstand the pressure generated in a maximum credible reactor accident without leaking.

3. The optimum fuel storage arrangement is one in which the shipping casks are used as a storage receptacle. The casks would be placed in the peripheral shield tanks. If loading of the casks is done by transfer flask, no additional shielding would be required during fuel transfer because the flask would be lowered to an adapter plate placed on the top of the cask. When transferring fuel by chute to the cask, an auxiliary shield would be placed around the top of the cask. : This shield would be U-shaped and would be placed with the opening toward the reactor. To minimize risk of damage to the peripheral tanks, it is desirable to have one fuel chute for each shipping cask required so that casks need not be moved after loading. Adequate cooling of the casks by natural convection can be achieved by design modifications to the cask to permit adequate flow area. The spent fuel will be cooled in the casks for not less than 90 days prior to shipment. Reduction in decay heat generation will then permit draining and sealing of the cask for shipment. During shipment, heat dissipation will be through the cask walls, and the cask surface temperature will remain below the maximum allowable limit of $180^{\circ} \mathrm{F}$. 
4. Based on best available figures for shielding, four casks will be required to house the PWR, $7 \times 7$ Type 2 core if a maximum gross weight of $20,000 \mathrm{lb}$ is not exceeded. If the maximum gross weight of 27,500 lb per shipping cask is allowed, only two casks would be required to ship this core. The BWR, rod type element would require six casks to ship the entire core with the $20,000 \mathrm{lb}$ weight limit and four casks to ship the core within the $27,500 \mathrm{lb}$ weight limit. If only part of the absorber loading is shipped, due to the longer life expectancy, further reductions in size or quantity of shipping casks may be realized.

5. The spent fuel shipping cask shielding analytical studies performed thus far are sufficient to provide an adequate basis for shield thickness determination, as well as optimum cask size and optimum decay time. Experiments and/or additional analytical calculations will be required to reduce conservatism in the shield thickness and provide the best final design. 


\subsection{BIBLIOGRAPHY}

1. Humphries, G. E., "PL-3 Concept Selection," AP Note-408, Alco Products, Inc., January 31, 1962.

2. "PL-2 Final Design Report, Vol.IV, 100-19030-CEND-135, June 30,1961 .

3. Rosen, S.S., et al, "Primary Shielding Calculations on the IBM-650 (ROC Codes)," APAE Memo-142, October 15, 1958.

4. Lence, T., Bujalski, "Gamma Production in the Core and Primary Shield of Thermal Reactors," APAE Memo No.145, October 8, 1958.

5. Rockwell, T., "Reactor Shielding Design Manual," 1956.

6. Morse, D. C. , "Machine Solution of Shielding Problems, " APAE Memo-52, September 5, 1956.

7. Scoles, J.F。, "Calculated Gamma Ray Spectra from U-235 Fission Products," NARF-58-37T, F2K-9-132, August 29, 1958.

8. Bopp, C. D。, Sisman, O, "How to Calculate Gamma Radiation Induced in Reactor Materials," Nucleonics, January, 1956.

9. Table of Functions and of Zeros of Functions National Bureau of Standards, November, 1954.

10. Kemp。S. No "Gamma Scanning Spent SM-1 Core I Fuel Elements Test 318," APAE Memo-281, April 6, 1961.

11. "Reactor Physics Constants," ANL-5800, July, 1958.

12. . DeYoung, $\dot{R}$. Co, "Containers for Irradiated APPR-1 Fuel Elements," APAE Memo No.63, October $31,1956$.

13. Poindexter, A. "Air Transportation of Radioactive Materials," RADC-TR-59-198, October, 1959. 


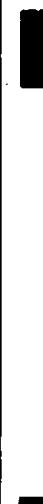

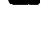


TABLE 1

SHIPPING CASK AND TRANSFER FLASK DATA SHEET

Reactor Concepts:

BWR Rod Type Core

BWR Plate Type Core

PWR Type 2, 7 × 7 Core

PWR Type $3,5 \times 5$ Core
- 24 elements, 9 cruciforms

- 60 elements, 8 or 9 cruciforms

- 45 elements, 7 absorbers

- 25 elements, 5 absorbers

Shipping Cask Data:

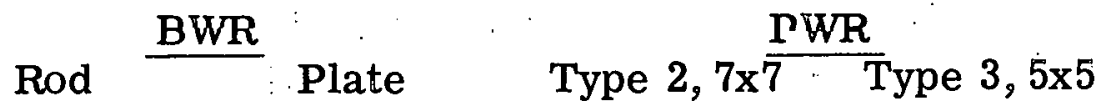

No. of casks required

Elements per cask

Absorbers per cask

Element length, in.

Absorber length, in.

Lead shielding, in.*

Bare cask weight, lb

Loaded cask on skid, lb

Basket opening, in. sq

$\begin{array}{ll}6 & 5 \\ 4 & 12\end{array}$

2 or 1

47.863

49.175

12

2 or 1

4

11 or 12

2

8. 75

32

37

10.2

2 or 1

31.625

23

10. 0

19,150

20, 560

19, 950

5. 875

18,650

20,150

5. 875

3. 0

12 or 13

3 or 2

31.625

23

11. 0 .

21, 100

22, 600

3. 0

Transfer Flask Wt., lb

22,200

16,350

14,000

14,000

* Shielding based on preliminary data. Later shielding figures from Alco ROC code adjusts figures to the following for 90 day decay périod:

Shielding

BWR, PL-2, 1/6 Core

BWR, SM-2, $1 / 5$ Core

PWR, SM-1, 1/4 Core

PWR, SM-2, $1 / 2$ Core
$9.67 "$

$10.04^{\prime \prime}$

$10.85^{\prime \prime}$

$11.12^{\prime \prime}$ 
TABLE 2

DECAY HEAT GENERATION RATES, PL-3 CORE

The following decay heat generation rates are based on the assumptions of $8 \mathrm{tMW}$ reference power and infinite reactor operation of a pressurized water core.

$$
\begin{aligned}
& \text { Decay Power Values (Based on Clancy-Stehn Curve) } \\
& \begin{array}{llll}
\mathbf{P} / \mathbf{P}_{\mathrm{O}} & \text { One day } & - & 0.0049 \\
& 90 \text { Days } & - & 0.0012
\end{array} \\
& \text { One Yéar - 0.0007 }
\end{aligned}
$$

\section{Fraction}

of Core

Full

$1 / 2$

$1 / 3$

$1 / 4$

$1 / 5$

$1 / 6$
Decay Heat

133,790

66,890

44,590

33,450

26, 760

22,300
Generation

32,760

16,380

10,920

8,190

6,530

5,460
$\mathrm{Btu} / \mathrm{Hr}$

19,110

9,560

6,370

4,780

3,820

3,190

Single Hot Element Heat Generation Rate after 24 Hr : Decay*

PWR, $5 \times 5$ Core Type 3

$8,020 \mathrm{Btu} / \mathrm{hr}$
PWR $7 \times 7$ Core Type 2

4, $455 \mathrm{Btu} / \mathrm{hr}$
BWR

Plate Type

13, $379 \mathrm{Btu} / \mathrm{hr}$
BWR

Rod Type

$8,360 \mathrm{Btu} / \mathrm{hr}$

* Values based on $150 \%$ of average 
TABLE 3

FUEL TRANSFER TOOLING FOR THE PL-3 REACTOR

1. Vapor Container Sling

2. Reactor Vessel Cover Sling with Adjustable Leg

3. Bolt Tensioner for Reactor Cover

4. Retrieving Tool

5. Stationary Element Handling Tool with Balancer

6. Control Rod. Element and Absorber Tool with Balancer

7. Tool Holder for the Following Tuuls

a. Reactor Cover Nut Runner

b. Stud Cap Runner

c. Jack Screw Runner

d. Core Cover Nut Runner

e. Core Cover Handling Tool

f. Dry Well Cover Nut Runner

g. Control Rod Cap Removing Tool

h. Fuel Chute Plug Tool

i. Shipping Cask Adapter Plate Tool

j. Shipping Cask Cover Pedestal Tool

8. Shipping Cask Sling

9. Miscellaneous Hand Tools, Jacks, etc.

(1) Can be used for dry well cover of PWR, if required.

(2) ' Two required. Remotely operated for PWR. Used for both pressure vessel and vapor container on BWR.

(3) Two required. Used only with PWR. Tool for BWR is part of the transfer flask assembly. Also used for spent fuel chute hopper.

(4) Two required.

(5) Used on PWR only.

(6) Used only if fuel transfer is by flask.

(7) Used only if fuel is stored in shipping cask for cool down. 
TABLE 4

REFUELING TIME ESTIMATE FOR BOILING WATER REACTOR

FUEL TRANSFER BY TRANSFER FLASK

1. Completely Filled Reactor Vessel with Water

$90 \mathrm{~min}$

2. Drain Water from Upper Shield Tanks, Remove and Store

105. $\mathrm{min}$

3. Remove Shielding from Control Rod Drive Housings

$45 \mathrm{~min}$

4. Remove and Store Control Rod Drive Units

$135 \mathrm{~min}$

5. Unbolt, Remove and Store Vapor Container Dome

$180 \mathrm{~min}$

6. Remove Drive Thimbles, Delatch and Remove Control Rods and Extensions

$180 \mathrm{~min}$

7. Crack Open Reactor Cover Flange Nuts

$75 \mathrm{~min}$

8. Drain Vessel to Flange Level and Remove Cover Nuts

$75 \min$

9. Remove and Store Reactor Vessel Cover

$45 \mathrm{~min}$

10. Place Shield Cover over Flange in Proper Position

$60 \mathrm{~min}$

11. Transfer Core by Transfer Flask ( 55 min per unit)

1,815 min

12. Remove shield cover and place in storage

$45 \mathrm{~min}$

13. Load Entire New Core in Reactor

$90 \mathrm{~min}$

14. Replace and Secure Reactor Vessel Cover

$300 \mathrm{~min}$

15. Replace Racks and Extensions, Latching to Control Rods

$90 \min$

16. Replace Drive Thimbles, Vapor Container Dome and Drive Housings

$360 \mathrm{~min}$

17. Replace Upper Shield and. Fill with Water

$120 \min$

18. Drain Reactor Vessel to Operating Level

$20 \min$

Total Time $=63 \mathrm{Hr}, \quad 50 \mathrm{Min}$ 
TABLE 5

REFUELING TIME ESTIMATE FOR PRESSURIZED WATER REACTOR

FUEL TRANSFER BY SPENT FUEL CHUTES TO

SHIPPING CASKS

1. Loosen, Remove and Store Vapor Container Cover Nuts

$150 \mathrm{~min}$

2. Remove and Store Vapor Container Cover

$45 \mathrm{~min}$

3. Fill Dry Cap, Unbolt, Remove and Store

$60 \mathrm{~min}$

4. Loosen, Remove and Store Reactor Cover Nuts

$135 \mathrm{~min}$.

5. Remove and Store Reactor Vessel Cover

$45 \min$

6. Remove and Store Core Cover

$15 \mathrm{~min}$

7. Remove and Store Control Rod Caps

$15 \mathrm{~min}$

8. Loosen, Remove and Store Fuel Chute Plugs ( 4 req $^{i} \mathrm{~d}$ )

$30 \mathrm{~min}$

9. Position Auxiliary Shield on Top of Cask (4 times)

$60 \mathrm{~min}$

10. Transfer Fuel Elements and Absorbers

$495 \mathrm{~min}$

11. Install Pedestal on Casks and Position Covers (4 req $\left.{ }^{\top} \mathrm{d}\right)$

$120 \mathrm{~min}$

12. Load New Core in Reactor

$270 \mathrm{~min}$

13. Replace, Seat and Tighten Fuel Chute Plugs

$30 \min$

14. Replace Cuntrul Rud Cajs and Core Cover

$30 \mathrm{~min}$

15. Reposition Reactor Cover and Tighten Nuts

$300 \mathrm{~min}$

16. Position Dry Cap, Tighten Bolts and Drain

$75 \mathrm{~min}$

17. Position Vapor Container Cover and Secure Nuts

$330 \mathrm{~min}$

Total Time $=36 \mathrm{Hr}$,

45 Min 
TABLE 6

CORE DATA

\section{Core}

Volume fraction of fuel

Volume fraction of stainless steel

Active fuel length, in.

Equivalent core radius, in.

Fuel enrichment (\% U-235)

Average fast flux, neuts $/ \mathrm{cm}^{2}-\mathrm{sec}$

Average thermal flux, neuts $/ \mathrm{cm}^{2}$-sec
PWR-7x7 PWR-5x5

Type 2

0.0192

0.1904

21. 75 .

11.2

93

1. $4 \times 10^{14}$

$1.4 \times 10^{13}$
Type 3

0.0240

0.2370

22. 0

8.30

93

1. $6 \times 10^{14}$

1. $2 \times 10^{13}$
BWR-

Plate

0.0125

0.1230

28. 0

13.0

93

$5.1 \times 10^{13}$

1. $0 \times 10^{13}$
BWR-

Rod

0.2045

0.1125

38.3

18.1

4.8

3. $4 \times 10^{13}$

$5.2 \times 10^{12}$

TABLE 7

SOURCE AND SHIELDING DATA (10 DAYS AFTER SHUTDOWN, INFINITE OPERATION)

\begin{tabular}{lllll} 
Core & $\begin{array}{lll}\text { PWR-7x7 } \\
\text { Type 2 }\end{array}$ & $\begin{array}{l}\text { PWR-5x5 } \\
\text { Type 3 }\end{array}$ & $\begin{array}{l}\text { BWR- } \\
\text { Plate }\end{array}$ & $\begin{array}{l}\text { BWR- } \\
\text { Rod }\end{array}$ \\
\hline
\end{tabular}

Macroscopic cross section of core, $\mathrm{cm}^{-1}$
(0.75 Mev $\left.\gamma^{i} s\right)$
0.1274
0.1586
0.08244
0.2722

Macroscopic cross section of core, $\mathrm{cm}^{-1}$
(2.Mev ' $s$ )
0.0768
0.0957
0.04974
0.1367

(1) Source Strength, Photons/ $\mathrm{cm}^{3} \mathrm{sec}\left(0.75 \mathrm{Mev} \gamma^{{ }^{\circ} \mathrm{s}} \mathrm{s}\right)$

$5.6 \times 10^{11}$

6. $6 \times 10^{11}$

2. $4 \times 10^{11}$

$9.9 \times 10^{10}$

(1) Source Strength, Photons/ $\mathrm{cm}^{3} \sec \left(2 \operatorname{Mev} \gamma:{ }^{\prime}\right)$

2. $0 \times 10^{11}$

2. $3 \times 10^{11}$

8. $2 \times 10^{10}$

3. $4 \times 10^{10}$

(2) Source Strength, Photons/ $\mathrm{cm}^{3}$ sec. (0.75 Mev $\left.\gamma^{\prime} \mathrm{s}\right)$

5. $6 \times 10^{11}$

6. $6 \times 10^{11}$

2. $4 \times 10^{11}$

9. $8 \times 1010$

(2) Source Strength, Photons/ $\mathrm{cm}^{3} \sec \left(2 \mathrm{Mev} \gamma:{ }^{\prime} \mathrm{s}\right)$

1. $8 \times 10^{11}$

2. $1 \times 10^{11}$

$7.6 \times 10^{10}$

$3.1 \times 10^{10}$

(1) With stainless steel activation

(2) Without stainless steel activation 
APPENDIX B - FIGURES

$625 \quad 038$ 


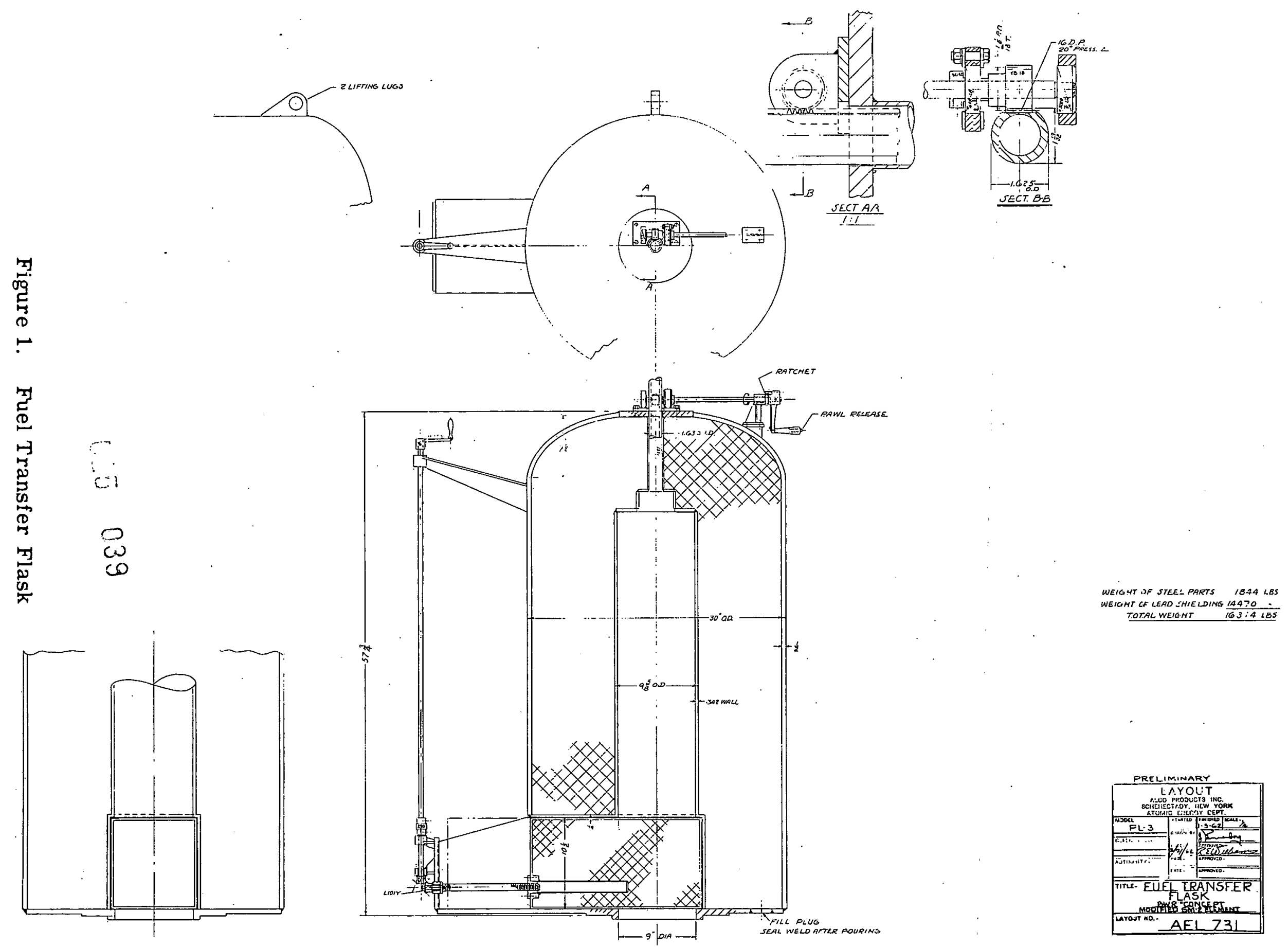




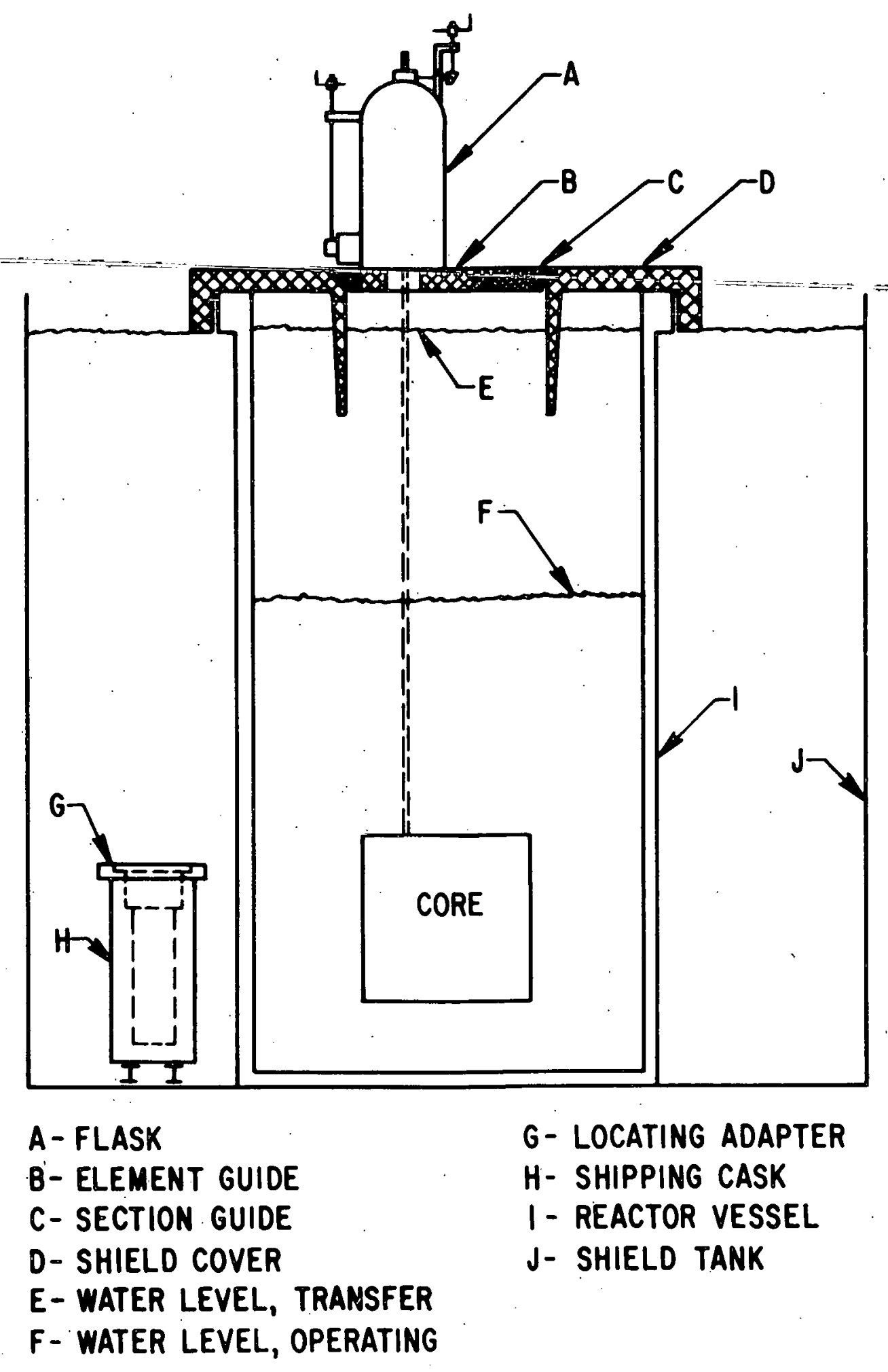

Figure 2. Refueling Condept Using Transfer Flask 

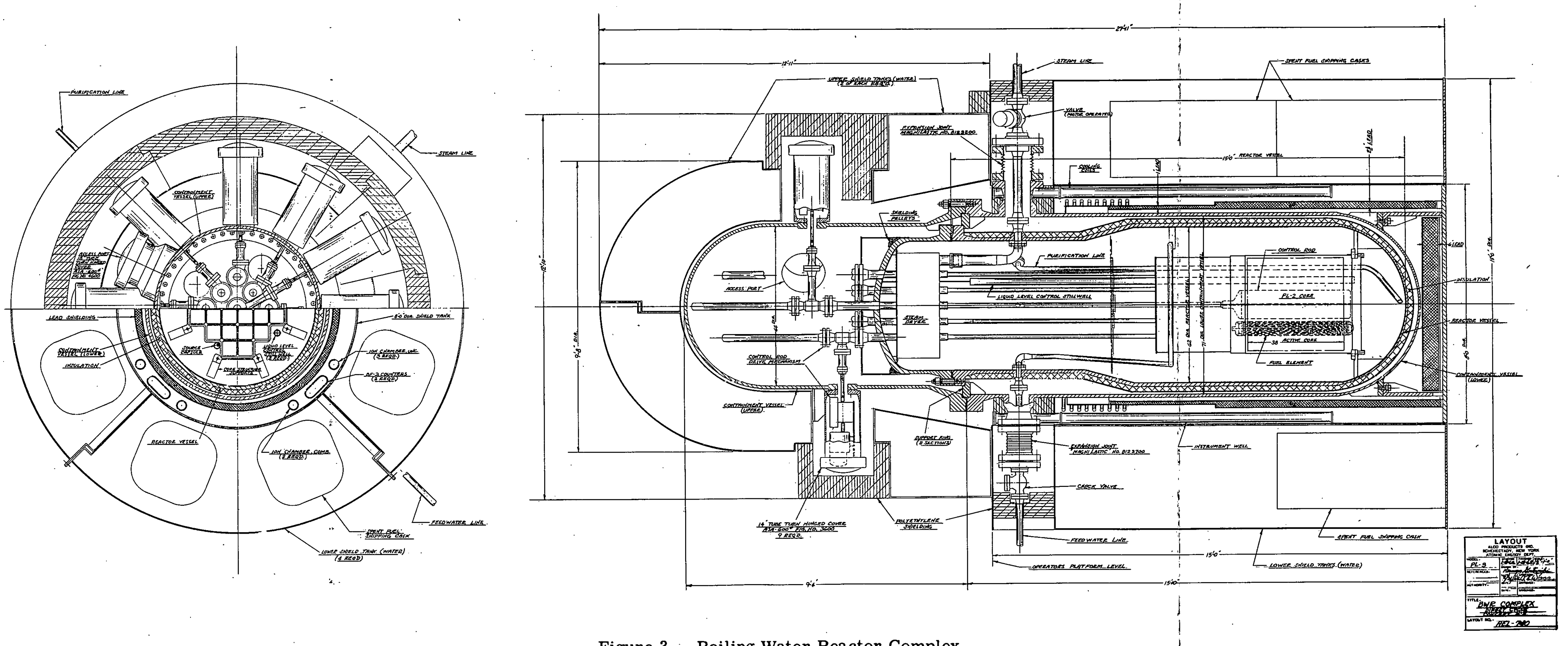

Figure 3. Boiling Water Reactor Complex 


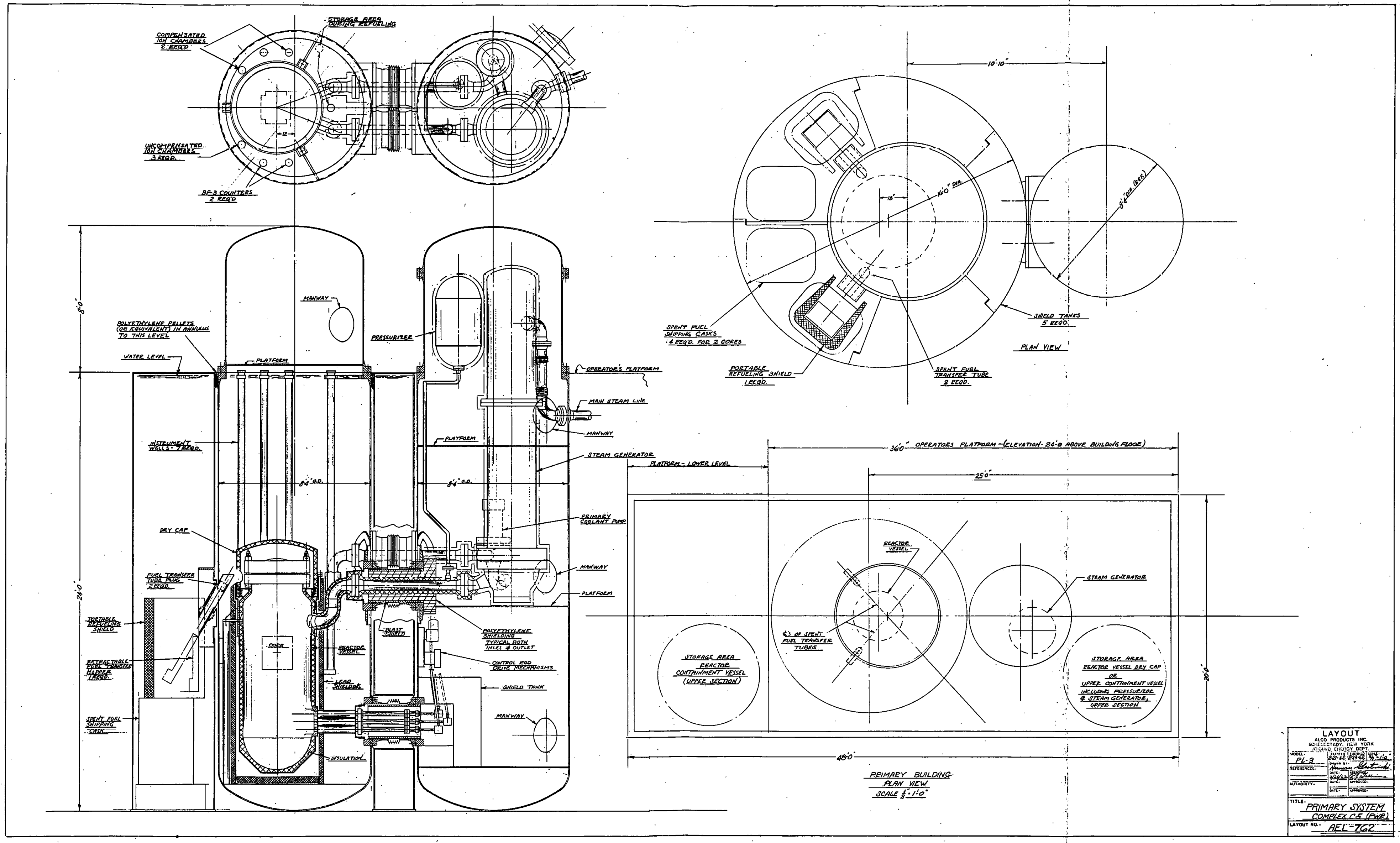




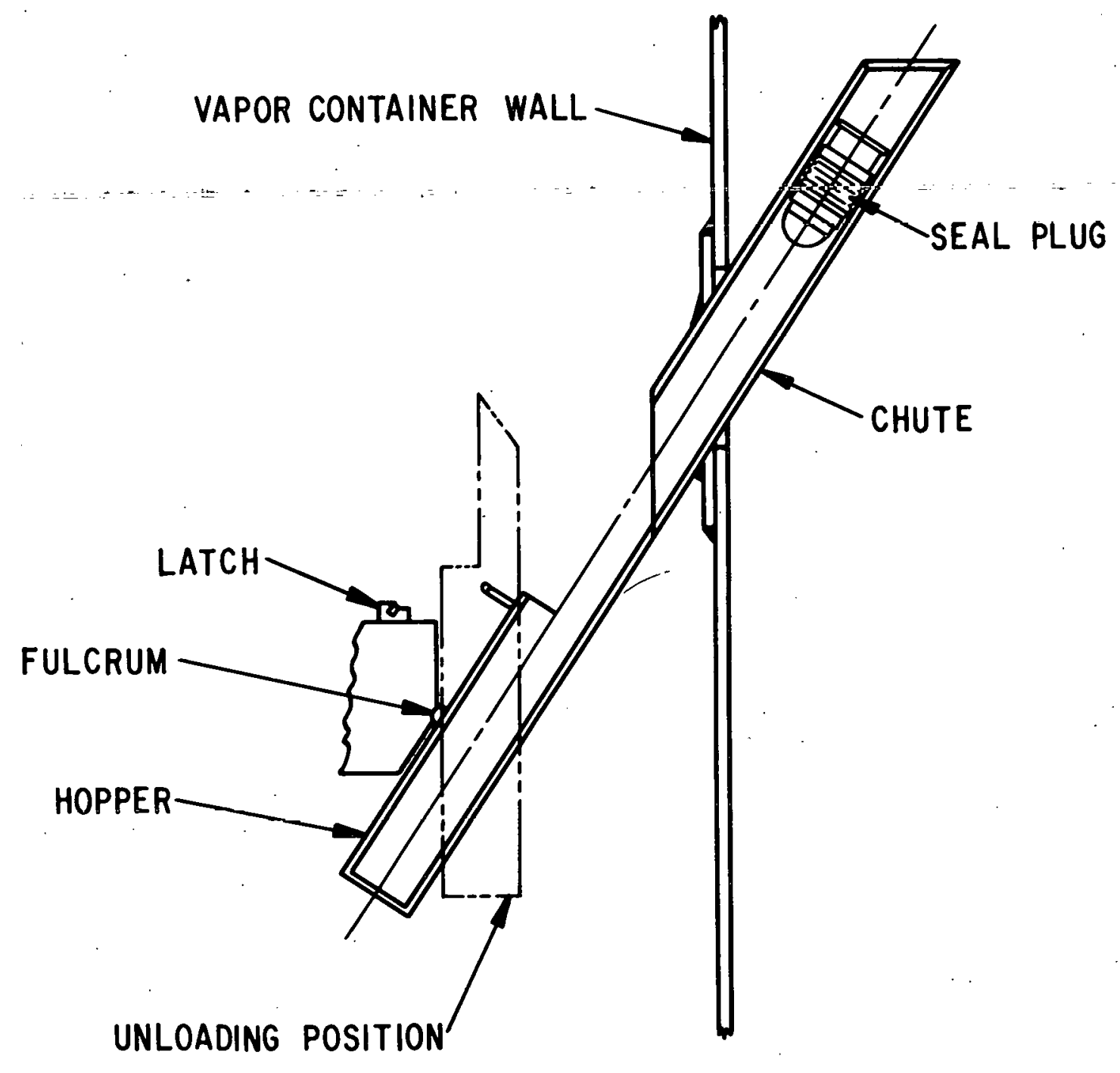

Figure 5. Spent Fuel Chute Concept

625043 

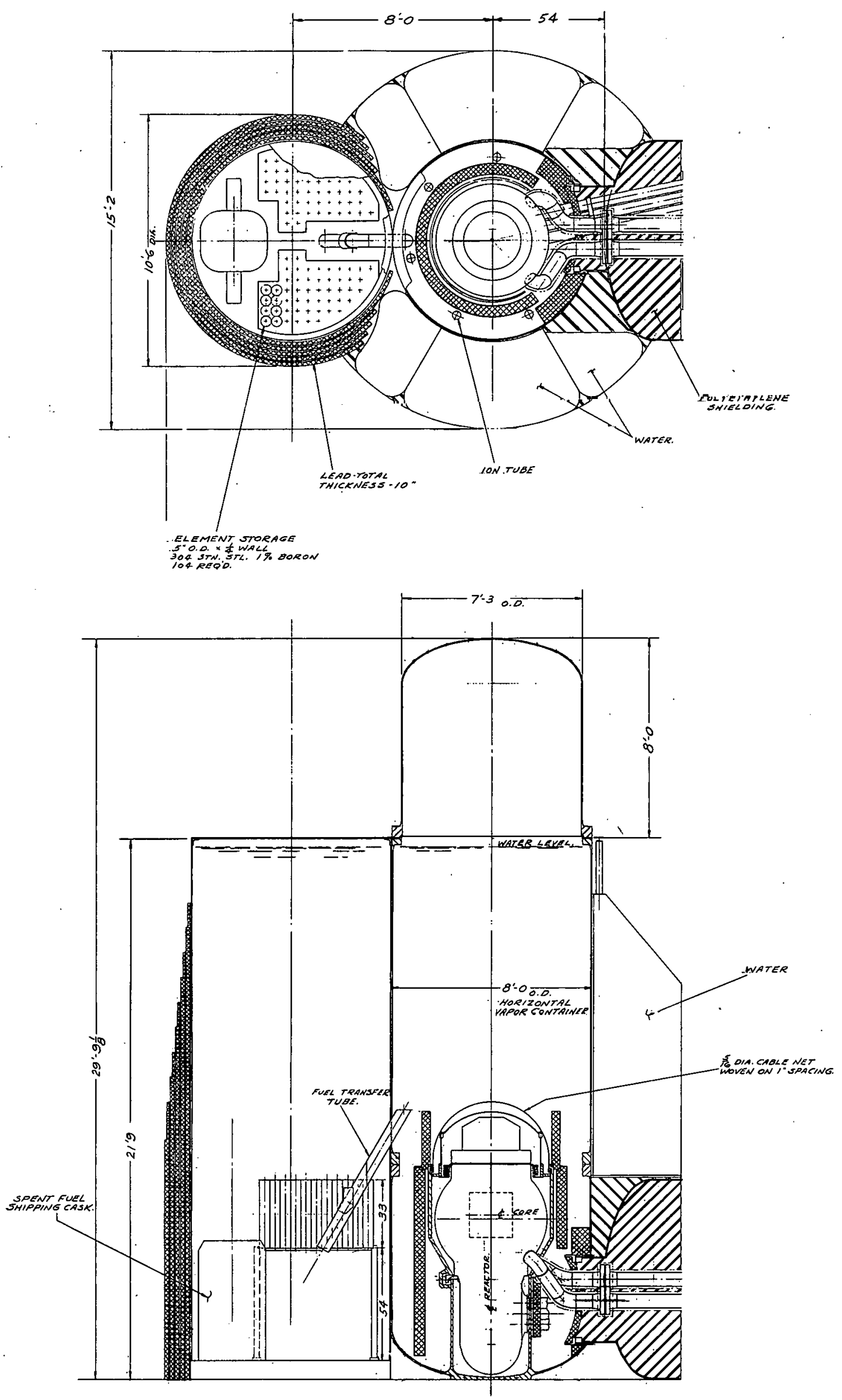

Figure 6. Primary System Complex A-3, PWR $625 \quad 044$ 


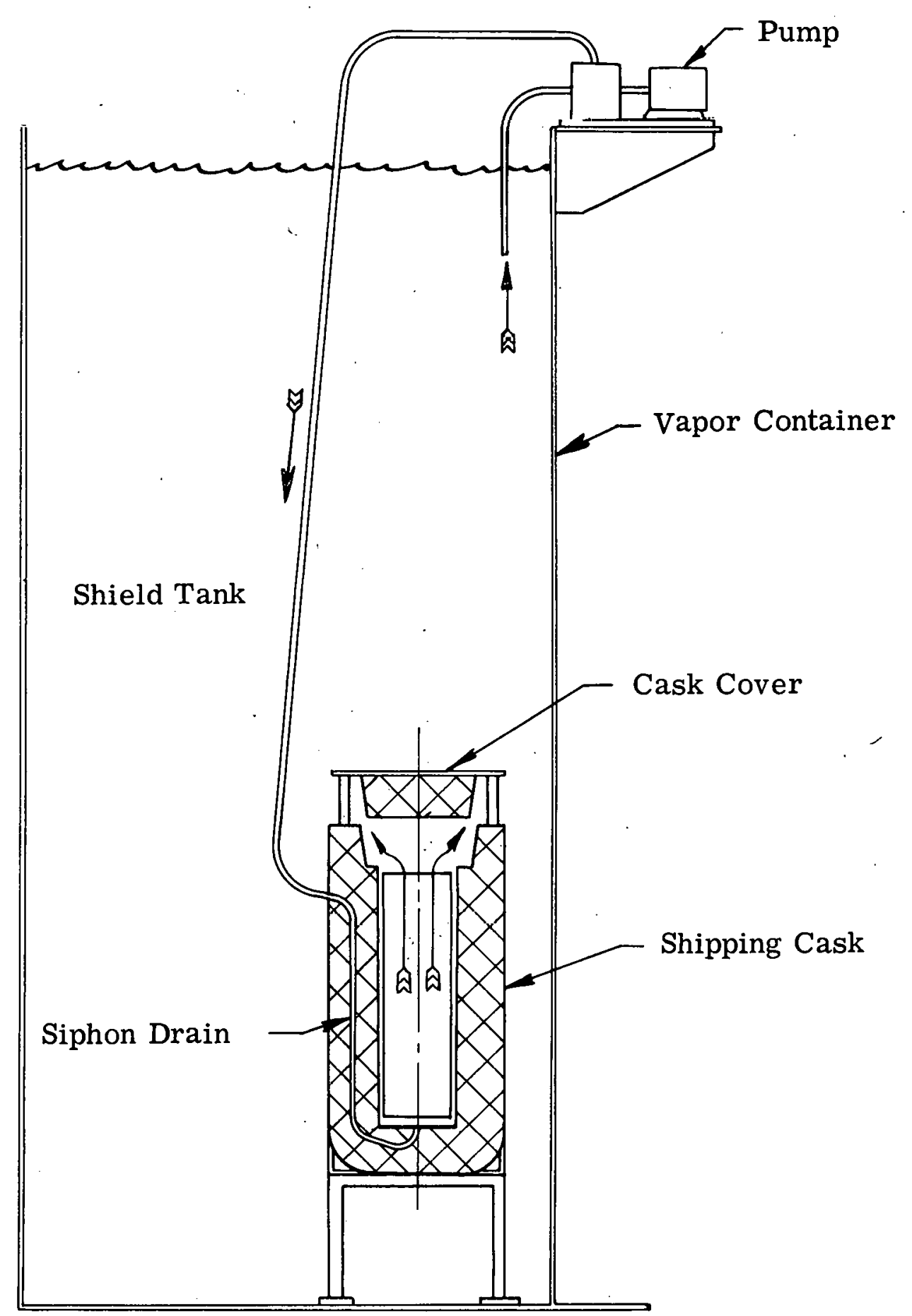

Figure 7. Storage Cask Forced Cooling System, PL-3 


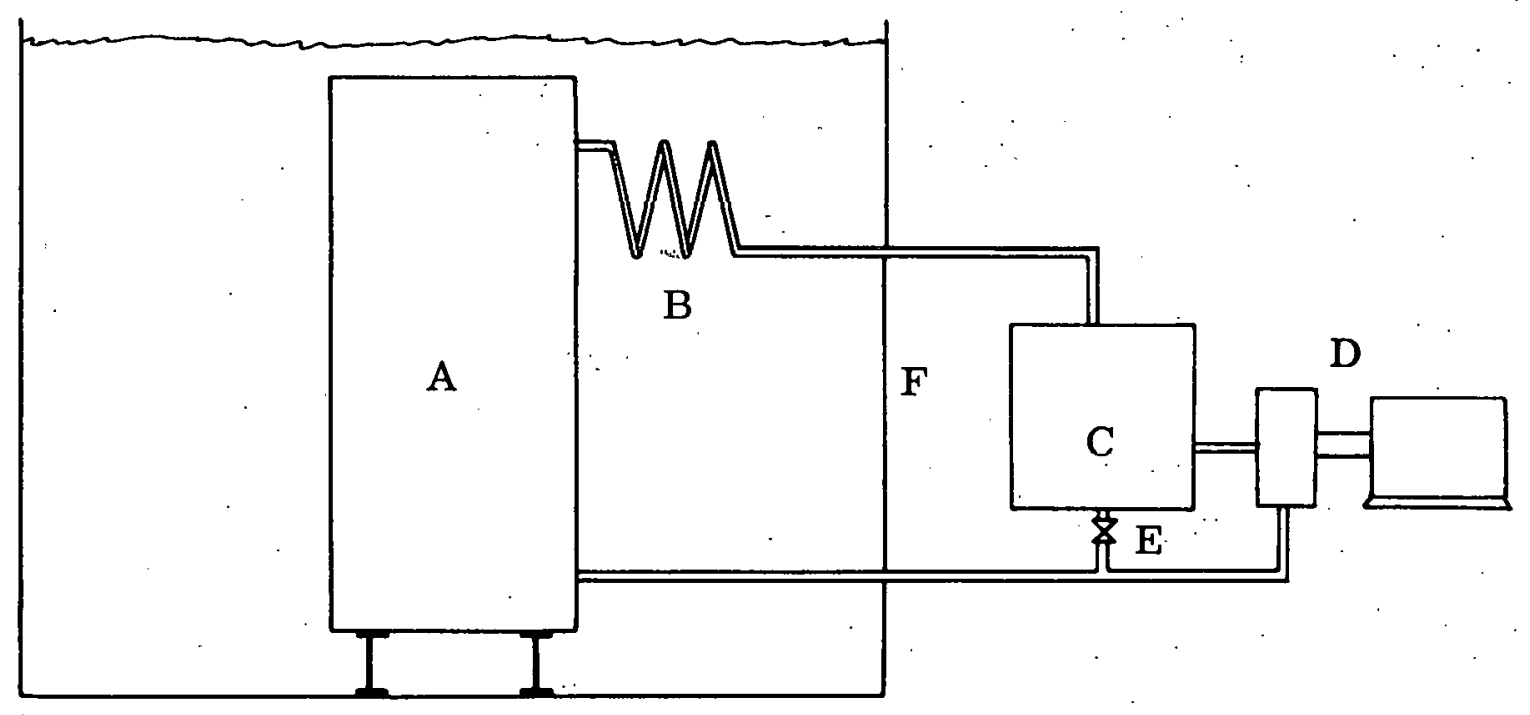
A - Spent Fuel Shipping Cask
B - Cooling Coil
C - Surge Tank Reservoir
D - Pump
E - Pump Bypass Valve
F - Skid Tank

Figure 8. Cask Cooling System 
6 ELEMEMT CASK (\$ CASKS REQUIRED)
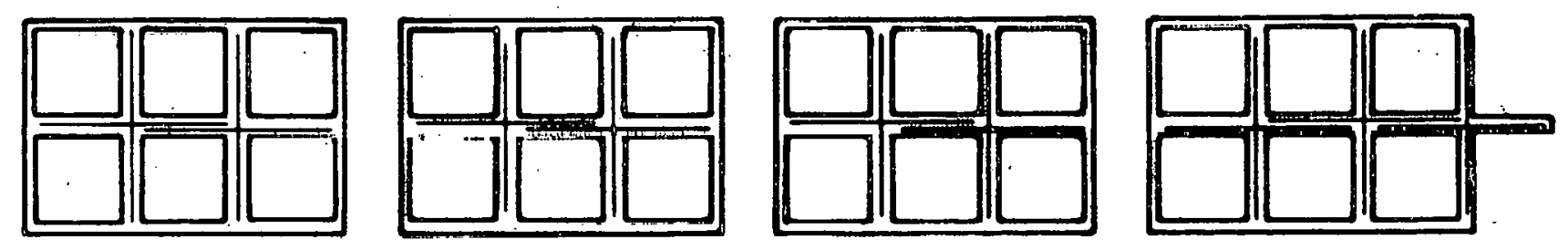

WEIGHT OF BARE CASK $=20,760$ \#

WEIGHT OF LOAOED CASK ON SKID $=23,160$.

5 ELEMENT CASK (5 CASKS REQUIRED)
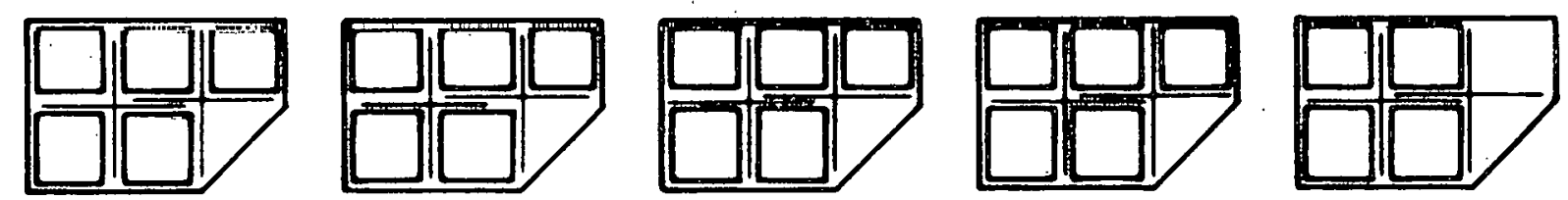

WEIGHT OF BARE CASK $=19,700^{\#}$

WEIGHT OF LOADED CASK ON SKID $=21,900^{\#}$

OPTIONS: 3 -SIX ELEMENT AMD 2 - FOUR ELEMENT CASKS

2-SIX ELEMENT AND 3-FOUR ELEMENT CASKS

4 ELEMENT CASK (6 CASKS REQUIRED)
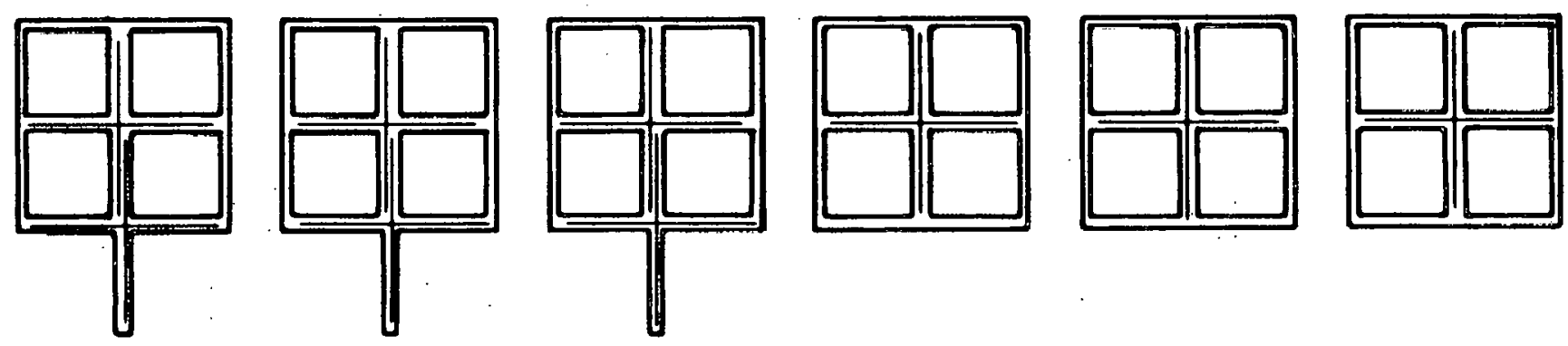

WEIGHT OF BARE CASK $=17,950^{\#}$ AND $18,400^{\#}$ WEIGHT OF LOADED CASK ON SKID $=19,950^{\#}$ AND $20,460^{\#}$

Figure 9. Cask Sizing Based on PL-2 Core (BWR Rod Type) 

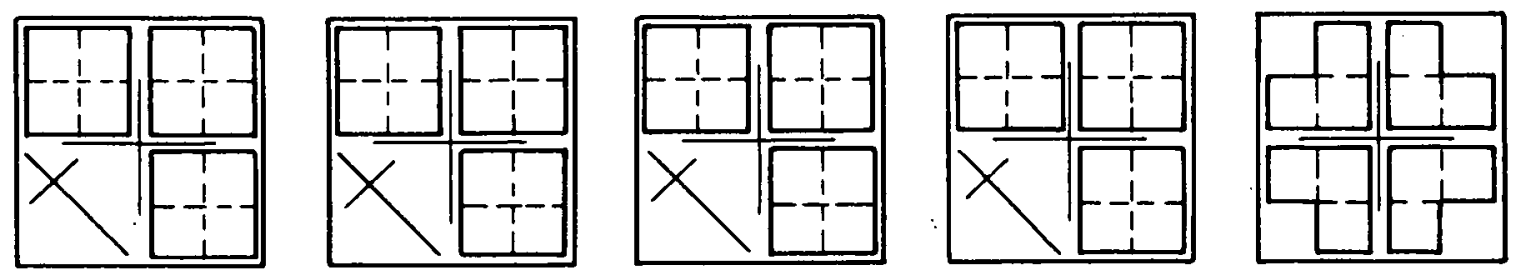

A. BWR SM-2 Cluster Elements, 9 Cruciforms, 5 Casks;

Weight Empty $=19,150 \mathrm{lb}$

Loaded Weight on Skid $=20,650 \mathrm{lb}$
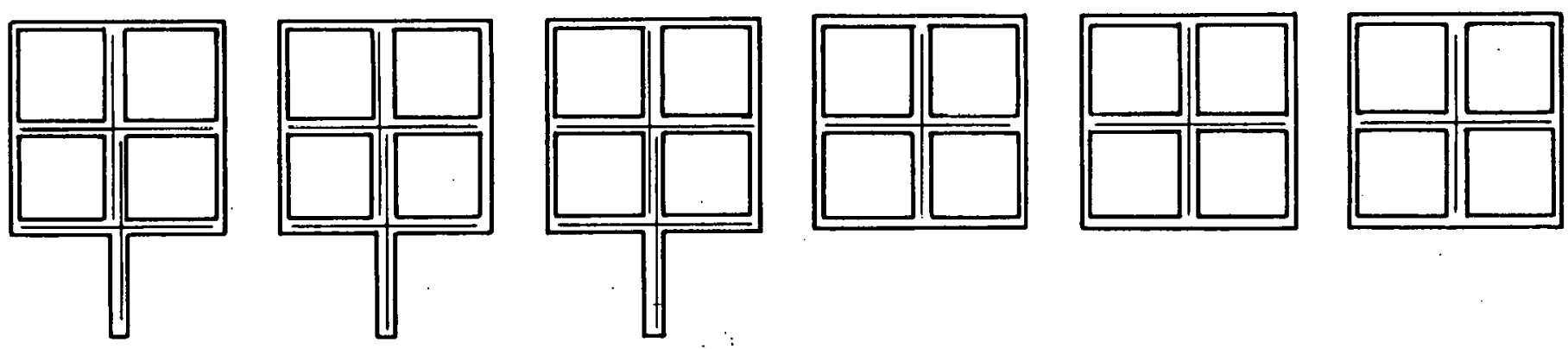

B. BWR

PL-2 Pin Type Elements, 9 Cruciforms, 6 Casks;

Weight Empty $=17,950 \mathrm{lb}$ and 18, $400 \mathrm{lb}$

Loaded Weight on Skid $=19,950 \mathrm{lb}$ and 20,460 lb
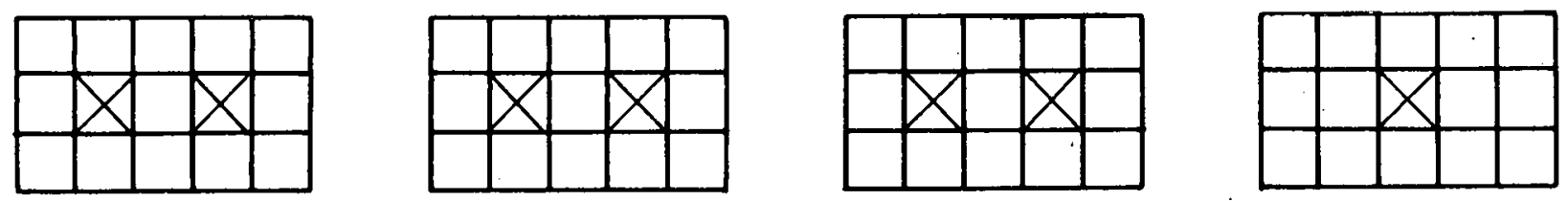

C. PWR SM-1 (or SM-2) Plate Type Elements, 7 Absorbers; 4 Casks;

Weight Empty $=18,650 \mathrm{lb}$

Loaded Weight on Skid $=20,150 \mathrm{lb}$

Figure 10. Optimum Shipping Cask Arrangement 


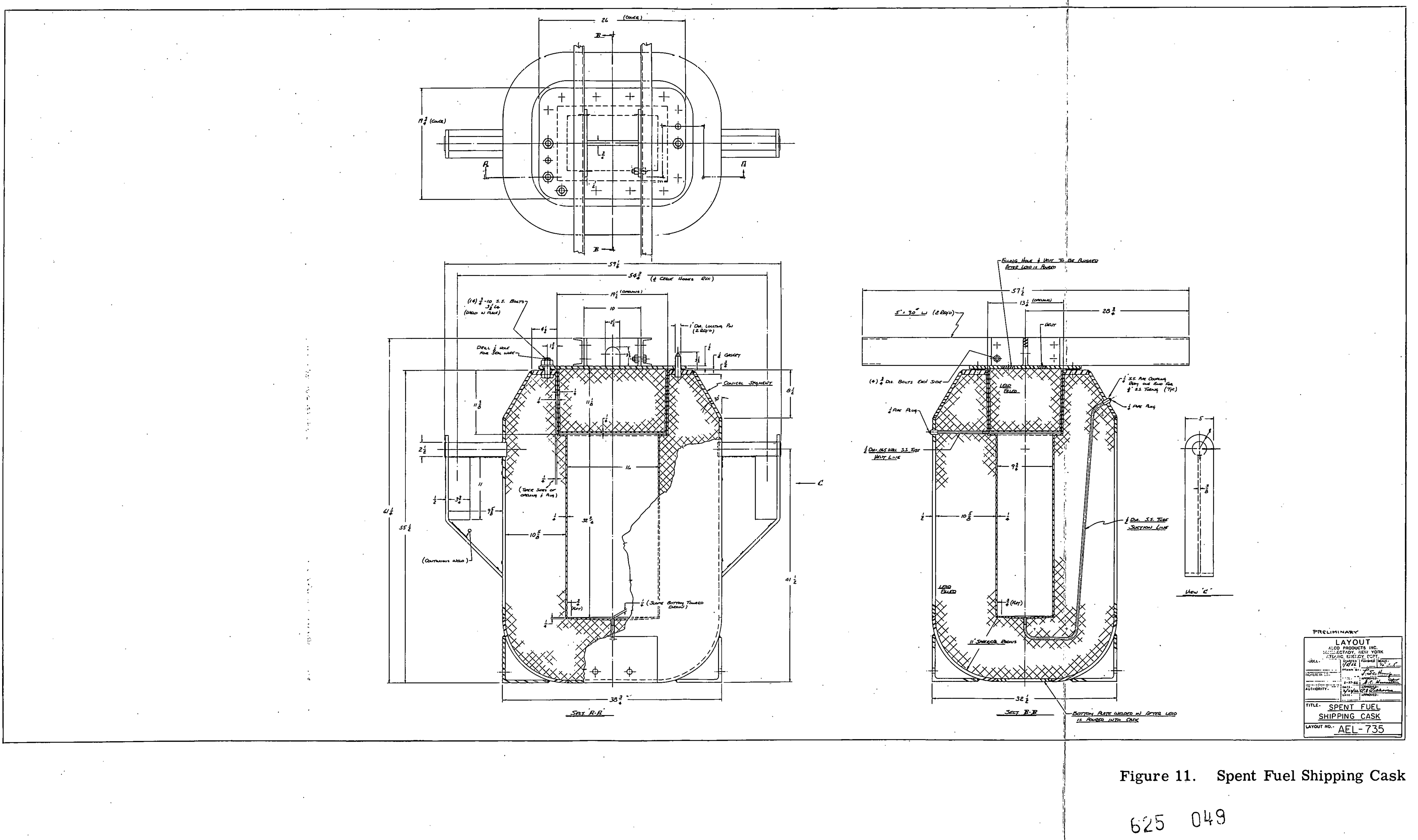




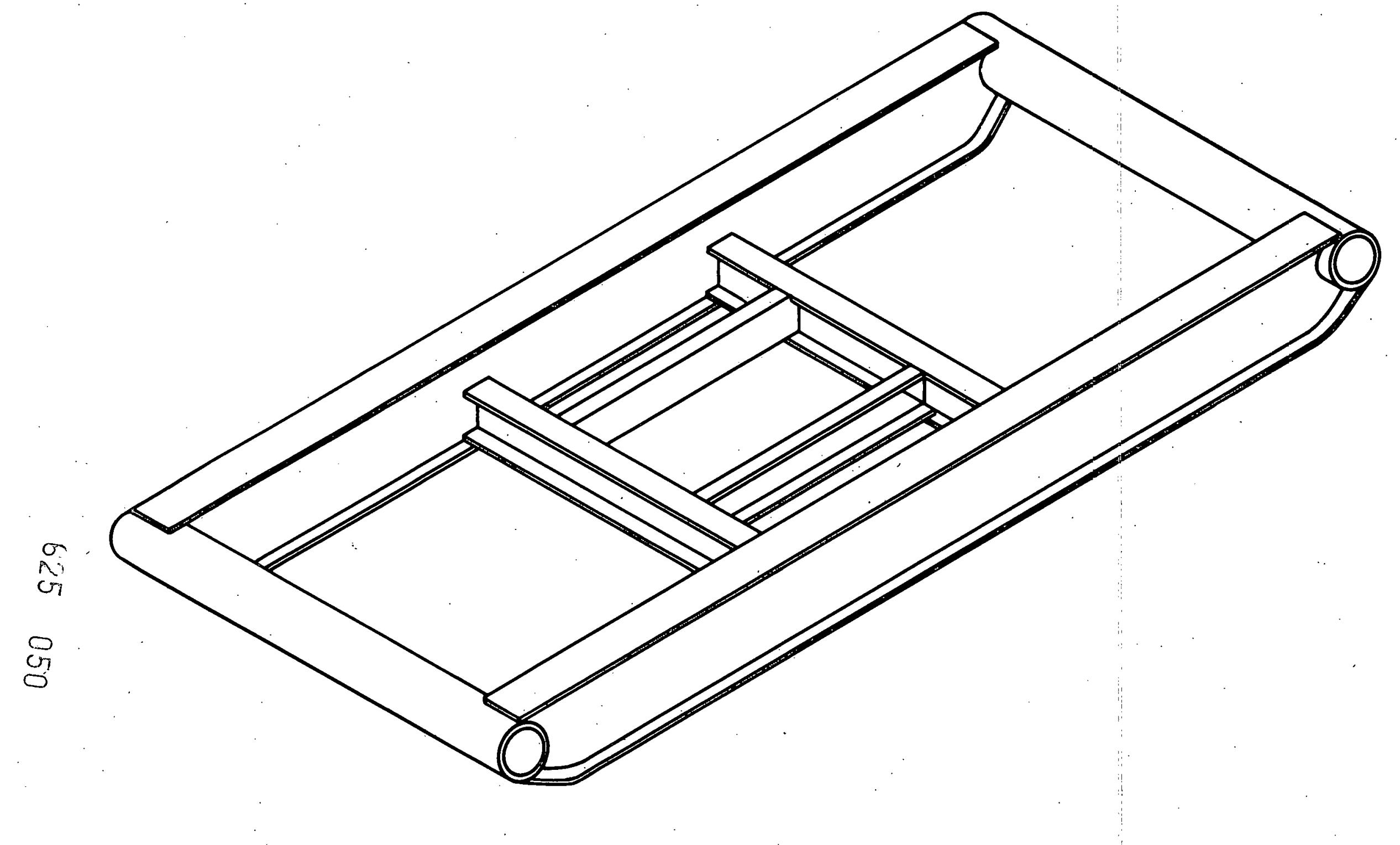

Figure 12. Proposed Skid - Spent Fuel Shipping Cask 


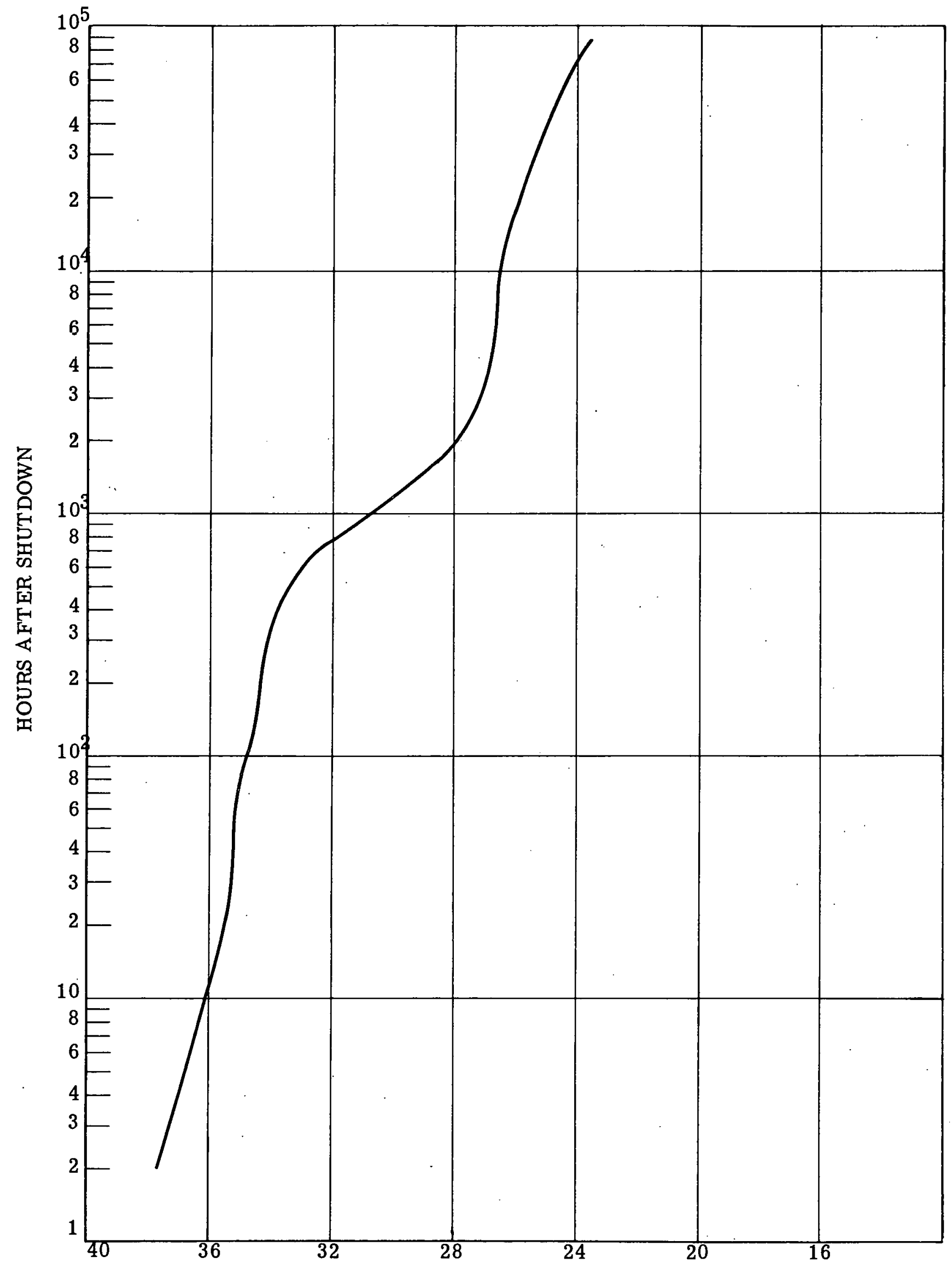

LEAD REQUIREMENTS FOR $10 \mathrm{MR} / \mathrm{HR}$ DOSE AT 1 METER - CM

Figure 13. Shielding Requirements for Shipping a PWR - 7 X 7 Type 2 Core 


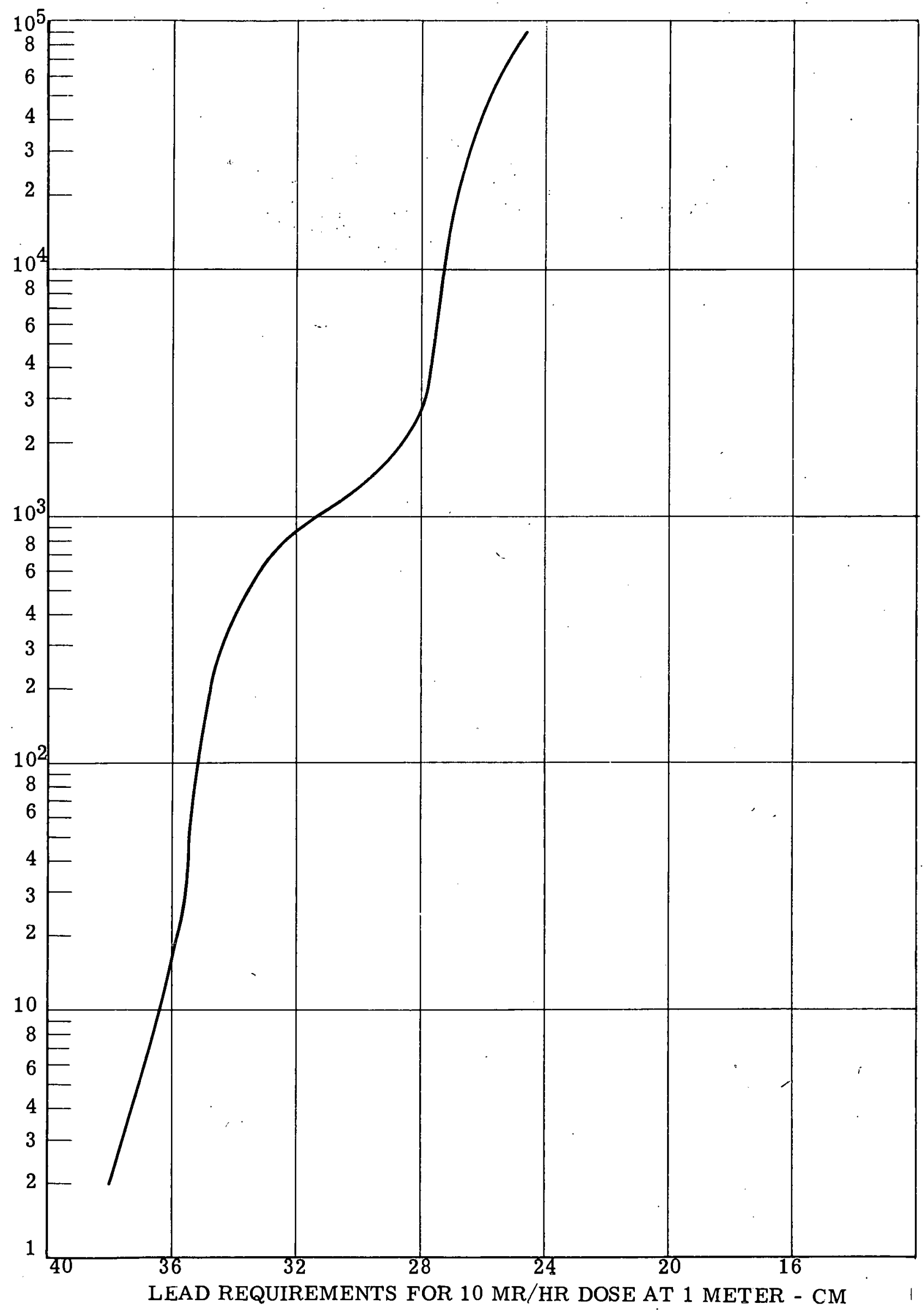

Figure 14. Shielding Requirements for Shipping a PWR 5 x 5 Type 3 Core $6<5 \quad 052$ 


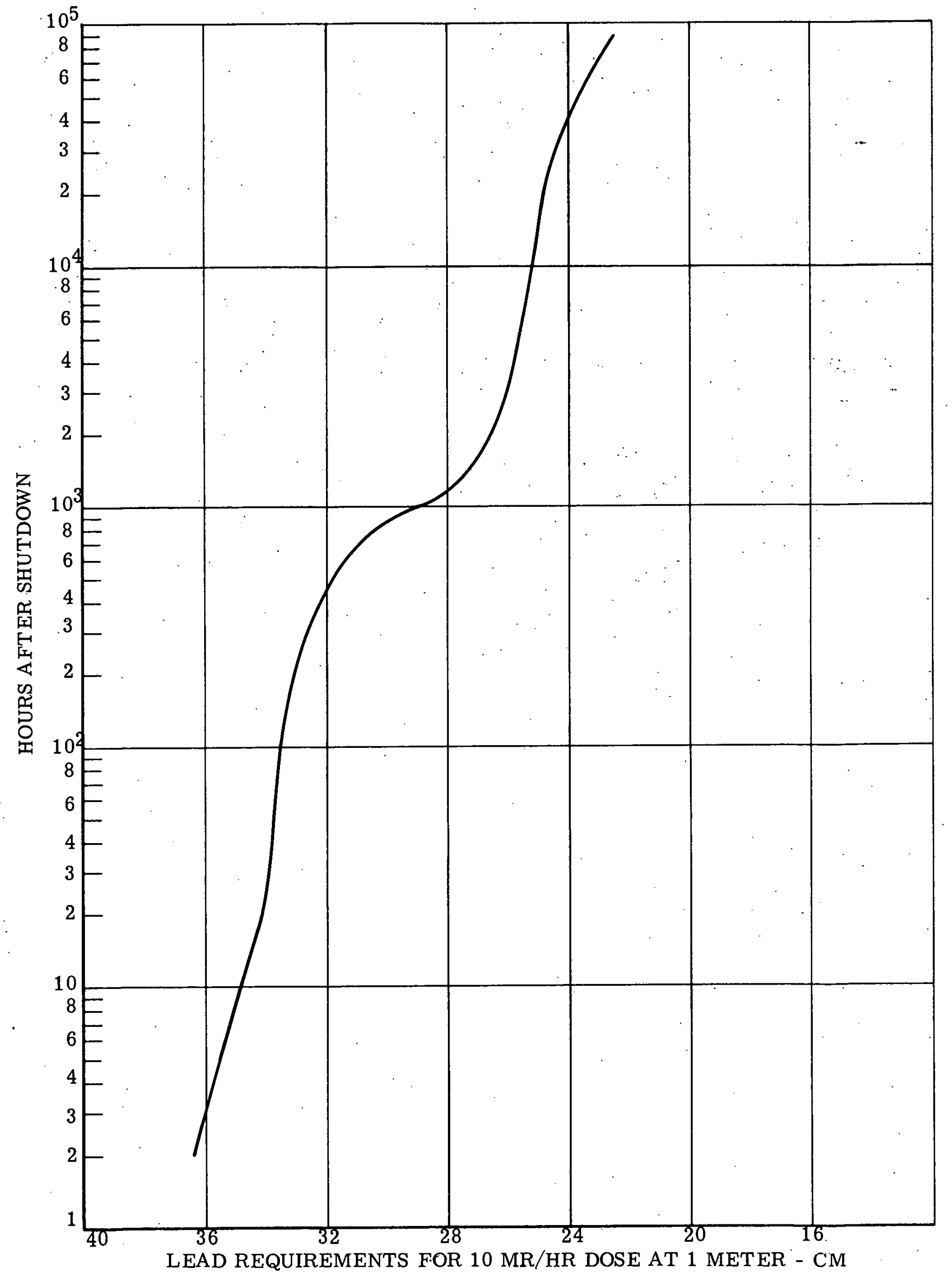

Figure 15. Shielding Requirements for Shipping a BWR Plate Type-Core 53 


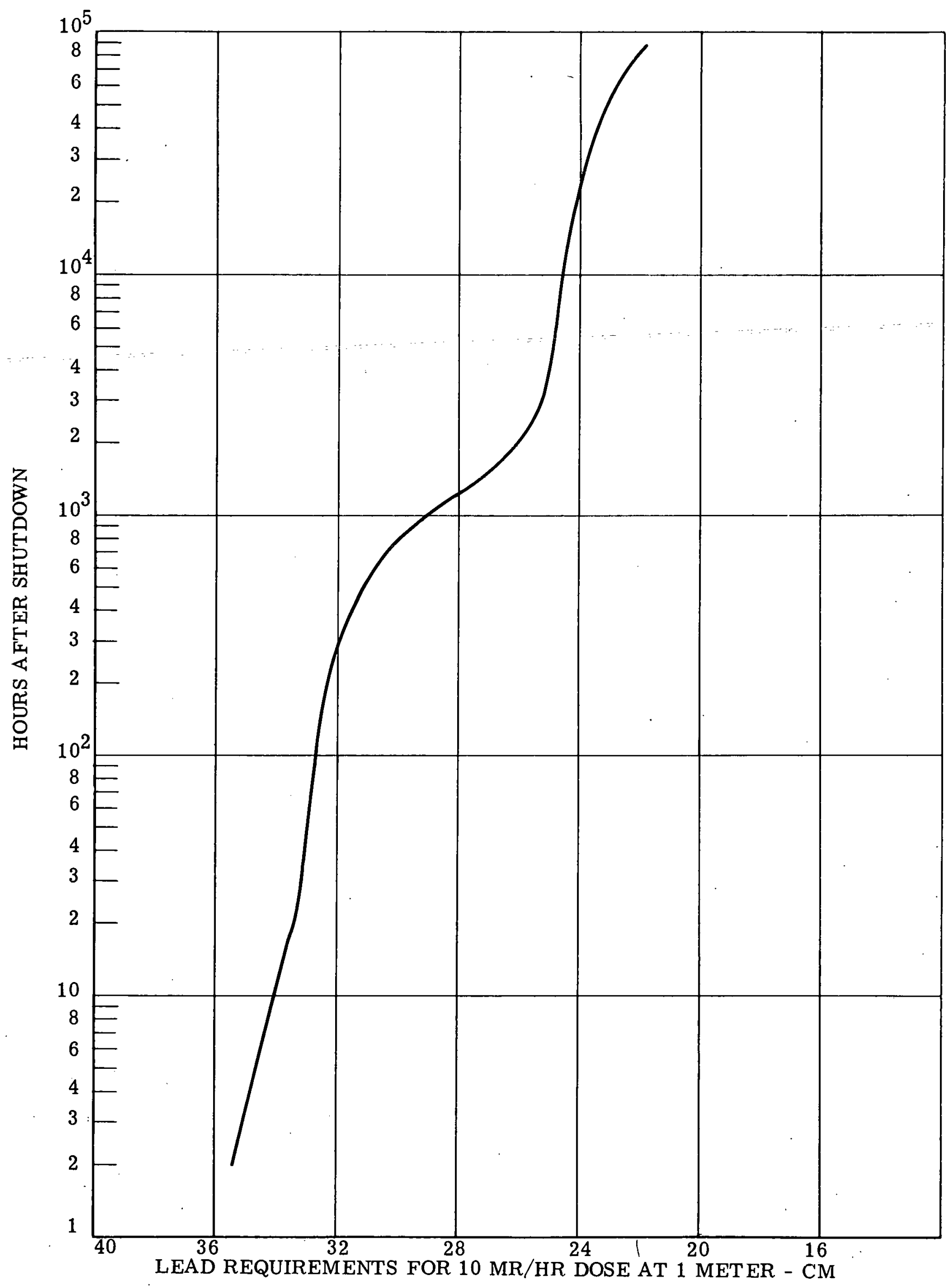

Figure 16. Shielding Requirements for Shipping a BWR Rod Type Core $625 \quad 054$ 


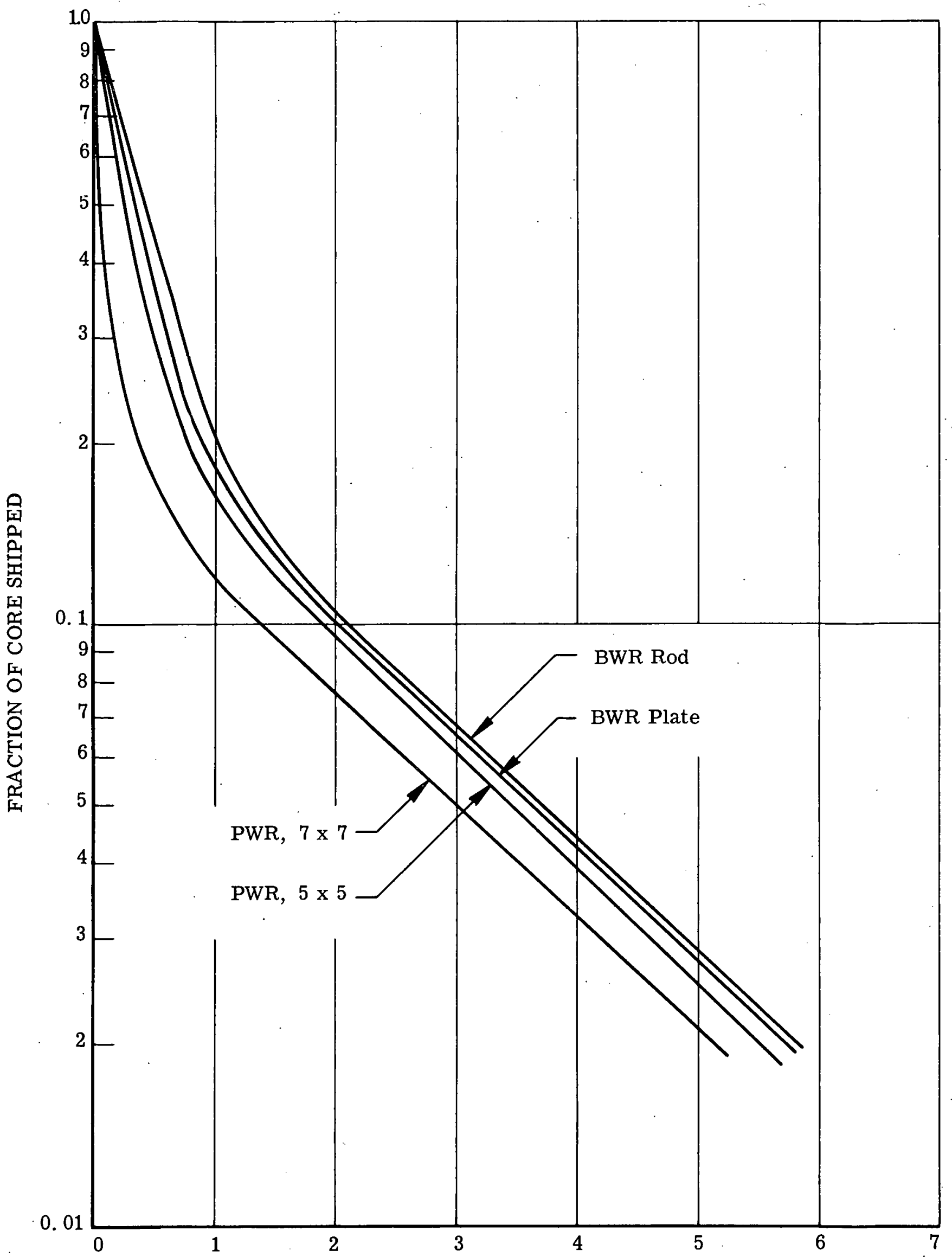

LEAD THICKNESS REDUCTION - CM

Figure 17. Shipping Cask Shield Reduction for Partial Cores

$$
625055
$$




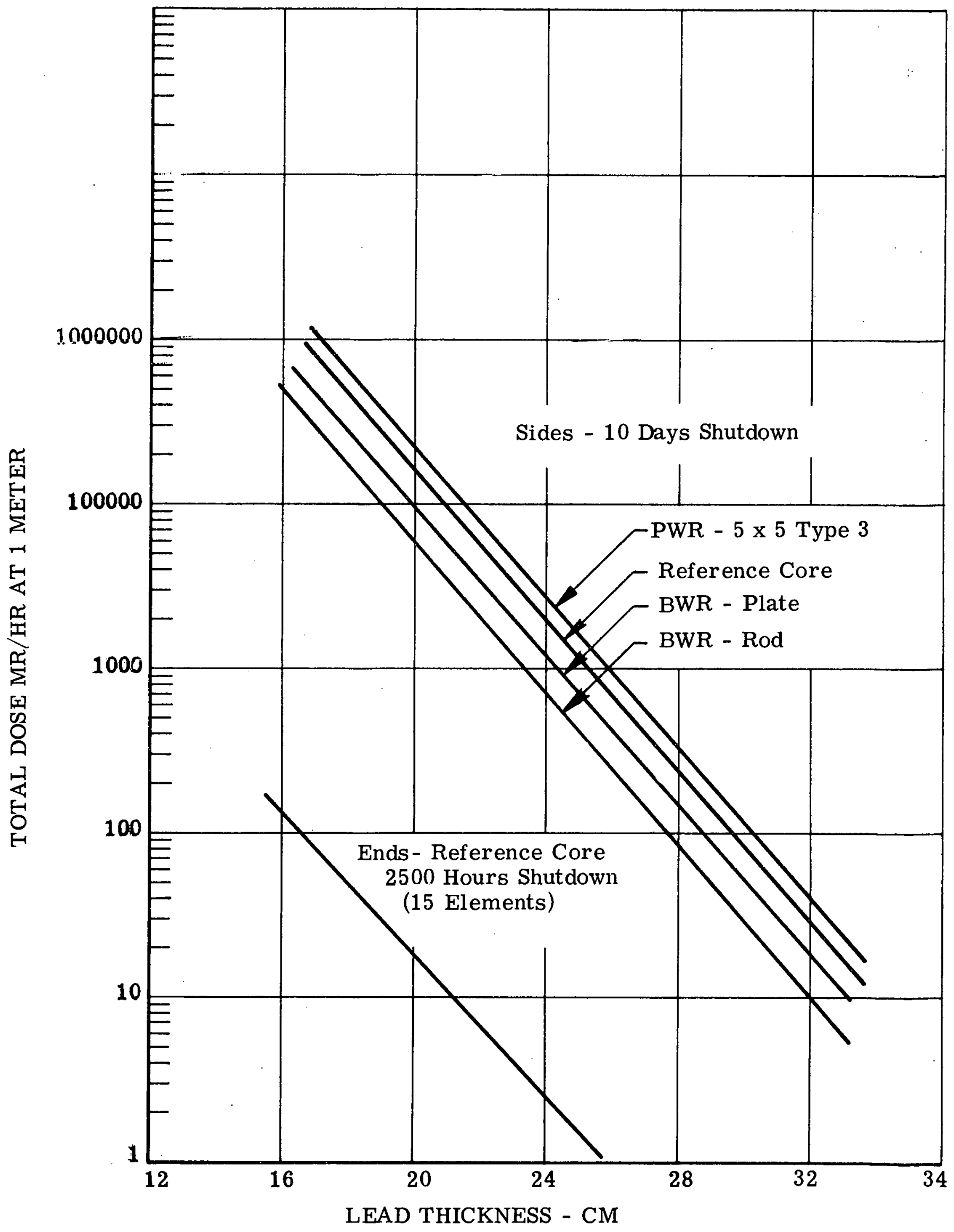

Figure 18. Shipping Cask Dose Attenuation

625056 